\title{
Taxonomy of the Solidago virgaurea Group (Asteraceae) in Poland, with Special Reference to Variability along an Altitudinal Gradient
}

\author{
Piotr Kieltyk • Zbigniew Mirek
}

(C) The Author(s) 2013. This article is published with open access at Springerlink.com

\begin{abstract}
The morphological differentiation and taxonomic treatment of lowland and high-mountain morphotypes within the Solidago virgaurea group are controversial. To clarify the taxonomic status of these taxa, we conducted a morphometric analysis of 1,746 individuals from 80 localities along an altitudinal gradient from the lowlands of northern Poland to the Carpathians and Sudetes of southern Poland. Multivariate morphometric analyses, cluster analyses and principal component analyses, were used to examine the morphological differentiation within the $S$. virgaurea group in Poland. Canonical discriminant analysis was applied to determine the morphological characters that best discriminate among the taxa. The stability of the high-mountain Solidago minuta morphotype was tested in an experimental field established in lowland Poland; individuals transplanted from various mountain sites were cultivated at this site, and the morphotypes remained stable in terms of their floral and vegetative characters. Multivariate analyses revealed two morphologically distinct taxa in the $S$. virgaurea group, which correspond to lowland $S$. virgaurea s. str. and high-mountain $S$. minuta as recognised in some European floras. The most important morphological characters for distinguishing the taxa are the number of tubular florets per capitulum, inner involucral bract width and involucre height. Vegetative and inflorescence characters appear to have less taxonomic value because they changed continuously with altitude. A key for identifying $S$. virgaurea and $S$. minuta in Poland is presented.
\end{abstract}

Keywords Altitudinal vicariants $\cdot$ Asteraceae $\cdot$ Multivariate morphometrics $\cdot$ Poland . Solidago $\cdot$ Taxonomy

\footnotetext{
P. Kiełtyk $(\bowtie)$

Faculty of Biology and Environmental Sciences, Cardinal Stefan Wyszyński University in Warsaw, K. Wóycickiego 1/3, 01-938 Warszawa, Poland e-mail: kieltyk@wp.pl

Z. Mirek

Institute of Botany, Polish Academy of Sciences, Lubicz 46, 31-512 Kraków, Poland
} 


\section{Introduction}

Groups of closely related taxa draw particular interest in taxonomy, phytogeography, ecology and evolutionary biology. In Central Europe, many closely related taxa have recently been studied morphologically and ecologically in such polyploid complexes as Centaurea stoebe (Španiel et al. 2008), Viola subsect. Viola (Hodálová et al. 2008) and Alyssum montanum (Španiel et al. 2011), as well as in groups with uniform ploidy levels, such as the Senecio nemorensis group (Hodálová and Marhold 1998; Hodálová 1999). Much attention is given to altitudinal vicariant pairs in the mountains of Central Europe. Taxonomic questions regarding these plants have been addressed in such groups as Cardamine amara (Marhold 1992), Sempervivum montanum (Letz and Marhold 1998) and Caltha palustris (Cieślak 2004); ecology has been addressed, for example, in Anthoxanthum odoratum-A. alpinum (Flegrová and Krahulec 1999; Filipová and Krahulec 2006).

The Solidago virgaurea group is widely distributed throughout the temperate and northern regions of Europe, Asia and North America (Hultén and Fries 1986; Meusel and Jäger 1992). This group is generally divided longitudinally into the European S. virgaurea L., the Siberian and Far Eastern S. dahurica (Kitag.) Kitag. ex Juz. and S. spiraeifolia Fisch. ex Herder, and the Chukotkan and North American S. multiradiata Aiton (Korobkov 2012). The European Solidago virgaurea L. is an exceedingly polymorphic taxon within which several closely related taxa have been described at various ranks from variety and subspecies to species (Yuzepchuk 1959; McNeill 1976; Wagenitz 1979). In a review of Solidago virgaurea L. variability in Europe and Asia, Slavík (2004) listed 17 taxa within this group (excluding taxa from Japan). Six names are present at the subspecies rank: S. virgaurea L. subsp. virgaurea, subsp. dahurica (Kitag.) Kitag., subsp. lapponica (With.) Tzvelev, subsp. leiocarpa (Benth.) Hultén, subsp. litoralis (Savi) Burnat and subsp. minuta (L.) Arcang. In addition, eleven names are listed at the "microspecies" rank: $S$. taurica Juz., S. caucasica Kem.-Nath., S. jailarum Juz., S. turfosa Woronow ex Grossh., S. armena Grossh., S. gebleri Juz., S. decurrens Lour., S. kuhistanica Popov, S. spiraeifolia, S. kurilensis Juz. and $S$. cuprea Juz. Two additional taxa are given by McNeill (1976), namely, S. macrorrhiza Lange, which may be referable to subsp. minuta, and subsp. centiflora Velen., the status of which is unresolved. Several different synonymous combinations for the taxa of this complex (Kereguélen 1999; Greuter 2006-2009) add to the confusion that exists regarding their taxonomic status and nomenclature.

Apart from its overall geographic variation, the $S$. virgaurea group exhibits differentiation along an altitudinal gradient between lowland and high-mountain populations in Europe, which Linnaeus described as separate species: $S$. virgaurea L. (Linnaeus 1753: 880; type locality "in Europae pascuis siccis", lectotype: Herb. Linn. No. 998.15 (LINN), designated by Garbari and Cecchi in Jarvis and Turland 1998), and S. minuta L. (Linnaeus 1763: 1235; type locality “in Pyrenaeis", lectotype: illustration in Hermann 1698: t. 245 - Virga Aurea Omnium minima Floribus maximis, designated by Garbari and Cecchi in Jarvis and Turland 1998), a high-mountain taxon from the Pyrenees. The altitudinal vicariance in the $S$. virgaurea group is also known in the Caucasus (Yuzepchuk 1959), Japan (Nishizawa et al. 2001) and North America (Porter 1893).

A lack of clarity in differentiating between the lowland and high-mountain taxa of the group and concerning their taxonomic status has led to the classification of 
European high-mountain populations at various ranks from species to variety: Solidago minuta L., S. virgaurea subsp. minuta (L.) Arcang., S. alpestris Waldst. \& Kit. ex Willd., S. virgaurea subsp. alpestris (Waldst. \& Kit. ex Willd.) Hayek \& Hegi, S. virgaurea var. alpestris (Waldst. \& Kit.) Gaudin, Solidago cambrica Huds. and Solidago monticola Boreau. In the Flora Europaea, McNeill (1976) treated S. lapponica With. and S. jailarum, which are currently considered as separate taxa (Rebristaya 1987; Korobkov 2012), as synonyms of $S$. virgaurea subsp. minuta. In European floras and checklists, the lowland and high-mountain taxa of this group are generally ranked at the subspecies (Pitschmann and Reisigl 1965; Rostański 1971; McNeill 1976; Wagenitz 1979; Dostál 1989; Rothmaler 1994; Slavík 2004; Greuter 2006-2009; Marhold et al. 1998) or species level (Yuzepchuk 1959; Hess et al. 1972). In Europe, the high-mountain taxon occurs in high mountain ranges from the Sierra Nevada through the Pyrenees and Alps to the Carpathians and Dinaric Alps, whereas the lowland S. virgaurea L. s. str. is common almost throughout Europe (Wagenitz 1979; Slavík 2004).

In this work, we have adopted the Linnaean names $S$. minuta L. for the European high-mountain taxon and $S$. virgaurea L. for the lowland taxon. Solidago virgaurea and $S$. minuta have the same ploidy level, which in various areas of its distribution has been determined to be $2 n=18$ (Skalińska et al. 1978; Wagenitz 1979; Slavík 2004; Marhold et al. 2007). The morphological characters that have been used to differentiate between $S$. virgaurea and $S$. minuta include plant size, leaf size and shape, type of inflorescence, stem indumentum, shape and dimensions of involucral bracts, capitulum dimensions and the number and size of florets (Szymkiewicz 1929; Rostański 1971; McNeill 1976; Wagenitz 1979; Slavík 2004). However, it has been emphasised that apart from two easily recognisable morphotypes, a wide range of intermediates exists between the lowland and high-mountain forms in the contact zone of the two taxa (Hess et al. 1972; Szafer et al. 1976; Skawińska 1981; Slavík 2004), which are not clearly distinguishable (Wagenitz 1979).

Pairs of altitudinal vicariants such as $S$. virgaurea and $S$. minuta exemplify closely related plant species that have drawn wider interest in terms of taxonomy, evolution and comparative ecology (cf. Krahulec et al. 1999). The present study of the S. virgaurea group in Poland aimed at $i$ ) examining overall morphological variation in the $S$. virgaurea group in Poland, $i$ ) determining the range of morphological variation for $S$. virgaurea and $S$. minuta, iii) considering whether characters exist by which the two taxa can be clearly separated, and if so, presenting the ranges of their values, and $i v$ ) testing the stability of the high-mountain morphotype by cultivating individuals transplanted from various altitudes together with individuals of the lowland morphotype in lowland experimental plots.

\section{Material and Methods}

\section{Plant Material}

Flowering plant materials were collected in the field along an altitudinal gradient from 80 localities of the Solidago virgaurea group in Poland during the seasons of 2005-2008. The investigated gradient extends from the lowlands of northern Poland 
to the alpine zone of the Western Carpathians and Sudetes in southern Poland. Most of the population samples (56) were collected from different altitudes of the Tatra Mts., from the foothills to the peaks. Each population sample usually consisted of 25 plants, but fewer plants were collected in some localities. Plants were collected in the field from relatively small areas (in mountains, up to ca. $15 \mathrm{~m}$ vertically and ca. $20 \mathrm{~m}$ horizontally; the areas were sometimes larger in the lowlands) and from phytosociologically uniform vegetation units. The sampled populations were morphologically homogeneous; apart from the intra-population variation of the natural populations, the plants collected at particular localities were very similar to one another. The statistical distributions of their quantitative character values deviated somewhat from normal distribution but were unimodal in every case. The population samples are listed in Appendix 1, and their distributions are given in Fig. 1.

Plants were dried and preserved as herbarium specimens for morphometric analyses. All study specimens were deposited in the KRAM (herbarium of the Institute of Botany at the Polish Academy of Sciences, Krakow).

\section{Common Garden Experiment}

To test the stability of the high-mountain morphotype and compare it with that of the lowland morphotype, we transplanted six plants per population from certain $S$. minuta and $S$. virgaurea populations to an experimental field established in the lowlands of central Poland (Wola Łagowska village at $320 \mathrm{~m}$ a.s.1.). The main collection from the Tatra Mts. was transplanted during the first year of the study (2005), and additional plants were transplanted in 2006. This paper presents the results of three and four years of cultivation for $62 \mathrm{~S}$. minuta plants from 14 localities and $47 \mathrm{~S}$. virgaurea plants from 11 localities that flowered in 2009. Because some plants did not have flowering shoots in 2009, the total number of specimens in the study is less than the number of transplanted plants (see Appendix $\mathbf{1}$ for a list of localities from which the plants were transplanted).

\section{Morphometric Analyses}

Twenty-five characters (17 continuous quantitative, seven discrete quantitative and one semi-quantitative) were measured or scored for 1,746 flowering plants from 80 populations, and eight ratios were derived from these characters (Table 1). Characters included those traditionally used for differentiating between $S$. minuta and $S$. virgaurea, as found in determination keys and floras, and others that appeared potentially useful for distinguishing the two taxa.

Multivariate analyses were performed for 32 quantitative characters (one semiquantitative character was excluded) and for a subset of nine characters consisting exclusively of capitulum and floret characters. Additional analyses on the subset of nine characters were performed to exclude vegetative characters with greater plasticity, which might reflect the habitat effect to a higher degree (e.g., thermal conditions that change along altitudinal gradients). Three floret and involucral bract characters (LFL, LW/LL and BW/BL) were not included in the subset of capitulum and floret characters due to their high variation in the populations of both taxa, which makes their separation less clear. 

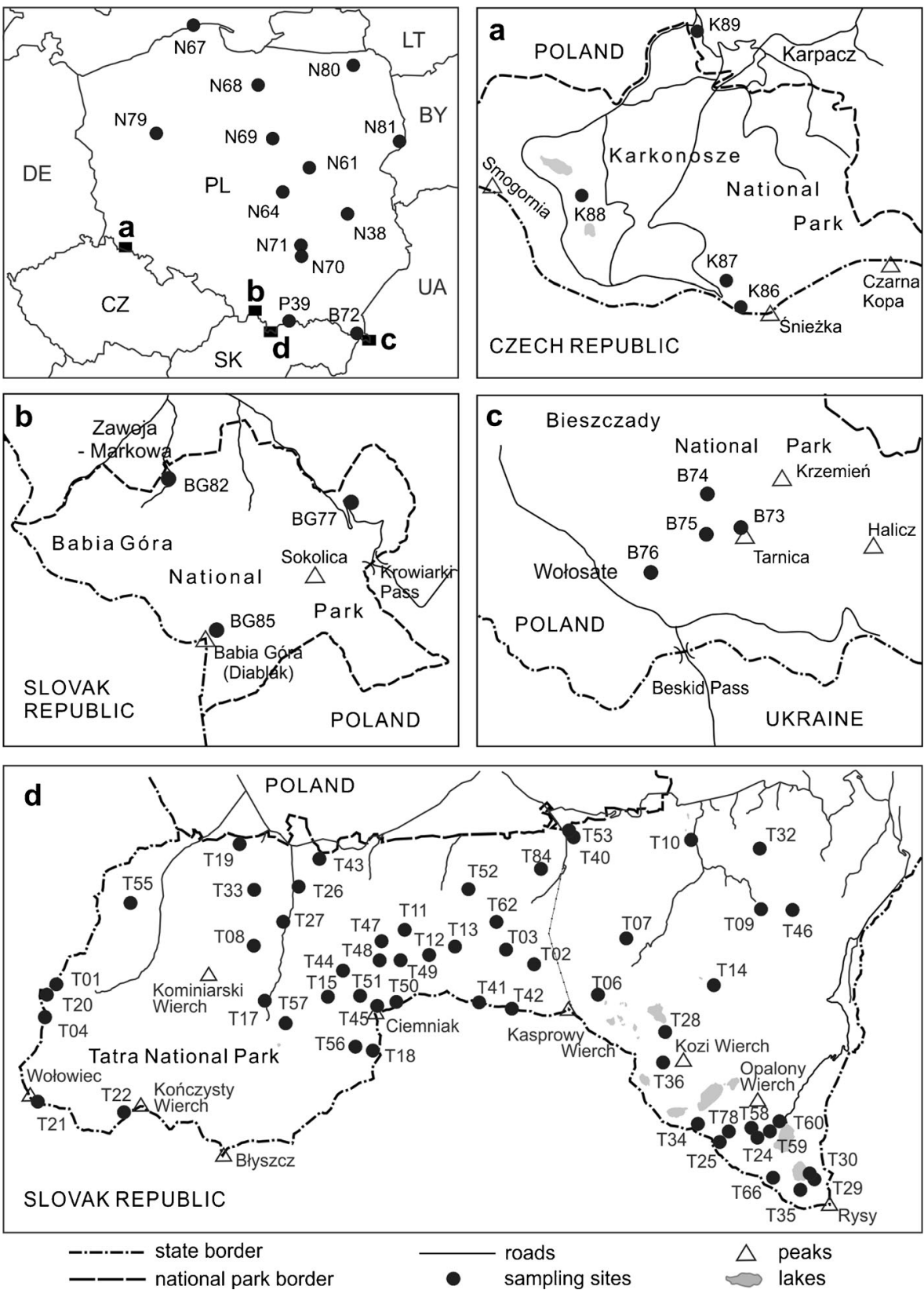

Fig. 1 Sampling sites of the populations of the Solidago virgaurea group. Detailed maps show the sampled populations in the Karkonosze Mts. (a), Babia Góra Mt. (b), Bieszczady Mts. (c), and in the Tatra Mts. (d)

For some plants it was not possible to measure or score all the examined characters; therefore, the case deletion method was applied to plants with missing data values. Thus, multivariate analyses based on individuals and 32 characters were performed for 1,380 individual samples (889 S. minuta and 491 S. virgaurea) and on nine characters for 1,578 individual samples ( 987 S. minuta and 591 S. virgaurea). 
Table 1 List of characters measured and used in the morphometric analyses

Continuous quantitative characters

PH Plant height from the base to the top of the inflorescence (mm)

InfL Inflorescence length from the lowest shoot node with developed capitulum to the top of the inflorescence (mm)

$\mathrm{IBL}^{\mathrm{a}} \quad$ Inflorescence branch length measured on branch at $1 / 3$ down of the inflorescence length (mm)

SL Capitulum stalk length (mm)

$\mathrm{CH}^{*} \mathrm{~b} \quad$ Capitulum height from the base of the capitulum to the top of the highest tubular florets (mm)

InvH$^{*} \quad$ Involucre height from the base of the capitulum to the top of the highest bract apices (mm)

$\mathrm{BL}^{*} \quad$ Inner involucral bract length $(\mathrm{mm})$

$\mathrm{BW}^{*} \quad$ Inner involucral bract width $(\mathrm{mm})$

LFL Ligulate floret length ( $\mathrm{mm}$ )

LW $^{*} \quad$ Ligule width $(\mathrm{mm})$

TFL ${ }^{*} \quad$ Tubular floret length (mm)

MLL $^{\mathrm{c}} \quad$ Middle stem leaf length (mm)

MLLL Middle stem leaf lamina length (mm)

MLLW Middle stem leaf lamina width ( $\mathrm{mm}$ )

$\mathrm{ULL}^{\mathrm{d}} \quad$ Upper stem leaf length (mm)

ULLL Upper stem leaf lamina length (mm)

ULLW Upper stem leaf lamina width (mm)

Discrete quantitative characters

NC Number of capitula per plant

NCB Number of capitula per single branch (the same branch described in IBL character above)

NSN Number of shoot nodes - the total number of nodes from the base of the plant to the top of the inflorescence

NB3 Number of inflorescence branches having more than three capitula

$\mathrm{NB}^{*} \quad$ Number of involucral bracts per capitulum

NLF $^{*} \quad$ Number of ligulate florets per capitulum

NTF $^{*} \quad$ Number of tubular florets per capitulum

Semi-quantitative character

$\mathrm{DHB}^{\mathrm{e}} \quad$ Differentiation of the height of involucral bracts:

1 - Bract apices form approx. one row on the involucre

2 - Bract apices form approx. two rows on the involucre

3 - Bract apices form approx. three rows on the involucre

4 - Bract apices form approx. four rows on the involucre

Ratio characters

InfL/PH, IBL/InfL, BW/BL, LW/LL, MLLW/MLLL, ULLW/ULLL, ULL/InfL, ULL/MLL

*Characters of the capitulum and florets used in a subset of nine characters in multivariate morphometric analyses.

${ }^{a}$ An inflorescence branch is defined as a structure growing from a node, having the form of a capitulum stalk when only one capitulum was present, to a well-developed branch with many capitula.

${ }^{\mathrm{b}}$ Characters concerning the capitulum and florets were obtained from one well-developed capitulum from the upper part of the inflorescence but excluding the uppermost capitulum on the shoot apex due to its larger size and often caused by two or more non-separated capitula growing together.

${ }^{\mathrm{c}}$ The middle leaf was defined as growing from the middle node between the first lower leaf and the upper stem leaf. In the case of an even number of nodes, the leaf from the lower node was taken.

${ }^{d}$ The upper leaf was defined as growing from a node one below the start of the inflorescence. The inflorescence starts from a node in which a developed capitulum grows on a stalk or branch.

${ }^{\mathrm{e}}$ Character scored and discussed in the text but not used in multivariate morphometric analyses. 
Pearson (parametric) and Spearman (non-parametric) correlation coefficients (Zar 2010) were computed for the matrix including all plants and 32 of their characters to eliminate pairs of highly correlated characters from further analyses (Legendre and Legendre 1998).

Cluster analyses based on populations (UPGMA, an unweighted pair-group method using arithmetic averages and the Ward method, using minimisation of the increase of the sum of squares; Podani 2000) were performed to generate a hypothesis on population groupings. The populations were represented by the mean values of the measured characters. The data were standardised using a zero mean and unit standard deviation, and the Euclidean distance was used to compute the secondary matrix.

Principal component analyses (PCA) (Sneath and Sokal 1973; Podani 2000) were performed on the basis of the correlation matrices of the measured characters. The analyses were run using both populations and individual plants as objects. This method was used to reduce the multidimensionality of the original character space and to display an overall variation pattern along the first two components that extracted most of the variation.

Canonical discriminant analysis (CDA), which maximises between-group differences (Klecka 1980), was performed with individual plants and all quantitative characters to determine the extent of morphological separation between the predefined groups and to evaluate characters to distinguish groups. This method was also used to test the results from cluster analyses based on population means. Two groups resolved by cluster analyses (see Results) were defined as CDA groups. Plants from three populations (T10, K86 and K88) that were resolved differently in cluster analyses (one time among populations of $S$. minuta, the other time among populations of $S$. virgaurea, depending on the classification algorithm and variables set used) were not included in the CDA calculation of the discriminant function but were present in the classifying stage using this function. Parametric classificatory discriminant analysis was performed to estimate the percentage of plants correctly assigned to predetermined groups (taxa). Discriminant analyses require a multivariate normal distribution of characters but have been demonstrated to be highly robust against deviations from this assumption (Sneath and Sokal 1973; Klecka 1980).

Means, standard deviations, minima, maxima, and the 10th and 90th percentiles were computed for all quantitative characters. The analyses were performed using Statistica ver. 7 (StatSoft Inc. 2004).

\section{Results}

\section{Morphometric Analyses}

The results of our cluster analyses based on population averages performed for two different algorithms (UPGMA and the Ward method) and two sets of characters (32 and nine characters) indicate that all 80 populations can be divided into two clusters, namely Group 1 and Group 2, which can be identified as $S$. virgaurea and S. minuta, respectively (Fig. 2); however, the results differ slightly between the two algorithms. The Ward method applied to the two sets of characters gave identical results in population clustering, grouping 29 populations in Group 1 and 51 populations 
a

Group 1

Group 2

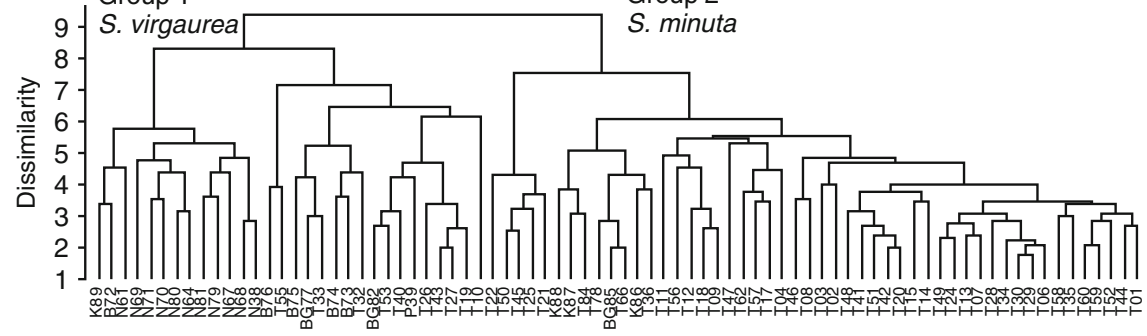

b

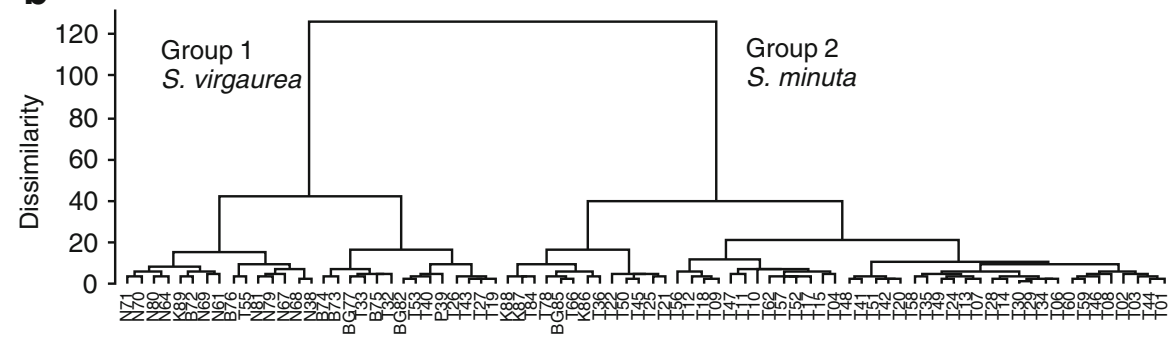

C

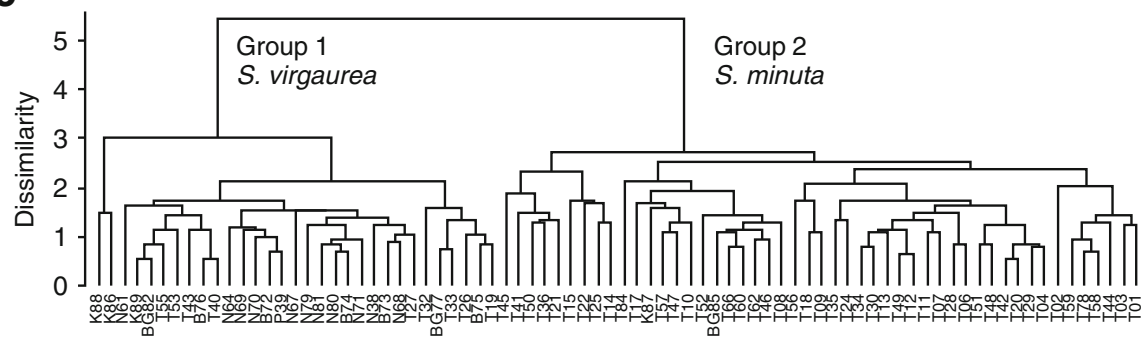

d

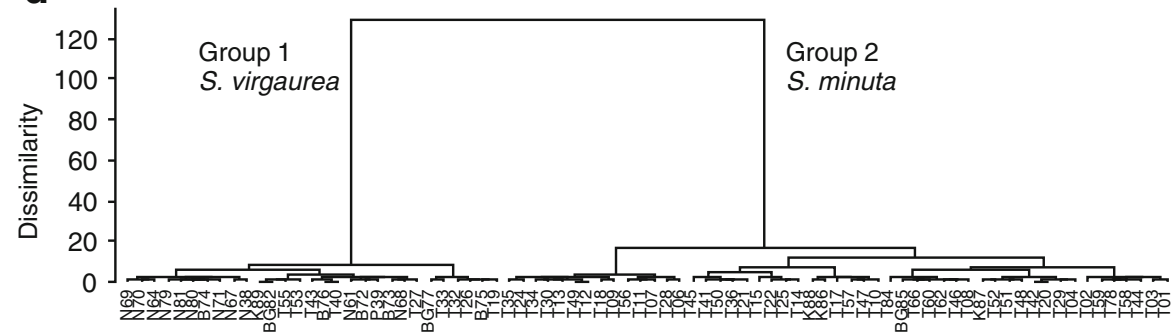

Fig. 2 Cluster analyses of 80 populations of the Solidago virgaurea group. a UPGMA, 32 characters; b Ward method, 32 characters; c UPGMA, nine characters; and d Ward method, nine characters

in Group 2 (Fig. 2b,d). Unlike the Ward method, a UPGMA based on 32 characters placed population T10 (Tatra Mts., 1,159 m a.s.1.) in Group 1 (Fig. 2a) whereas a UPGMA based on nine characters placed populations K86 and K88 (Karkonosze Mts., 1,404 $\mathrm{m}$ a.s.l. and 1,164 $\mathrm{m}$ a.s.l., respectively) in Group 1, but these populations appeared to be separate from the rest of the populations in Group 1 (Fig. 2c).

In the ordination diagrams of PCA based on population samples (Fig. 3a,b), the populations of $S$. virgaurea and $S$. minuta formed two groupings; $S$. virgaurea is 
a

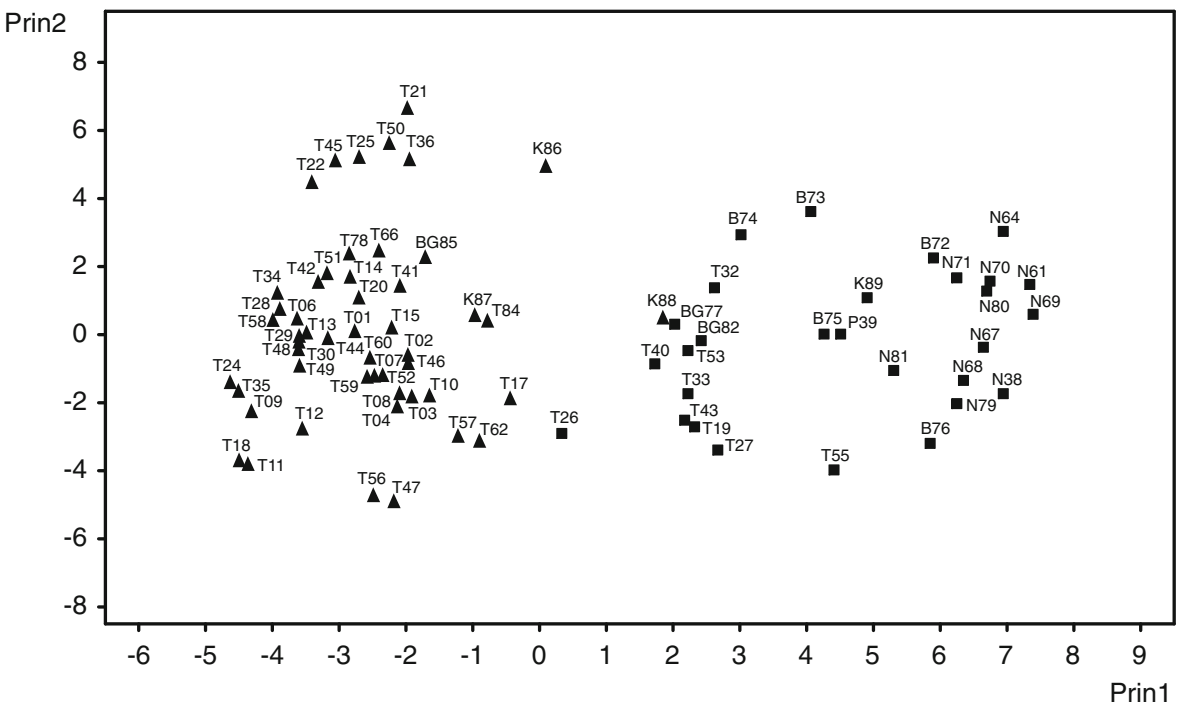

b

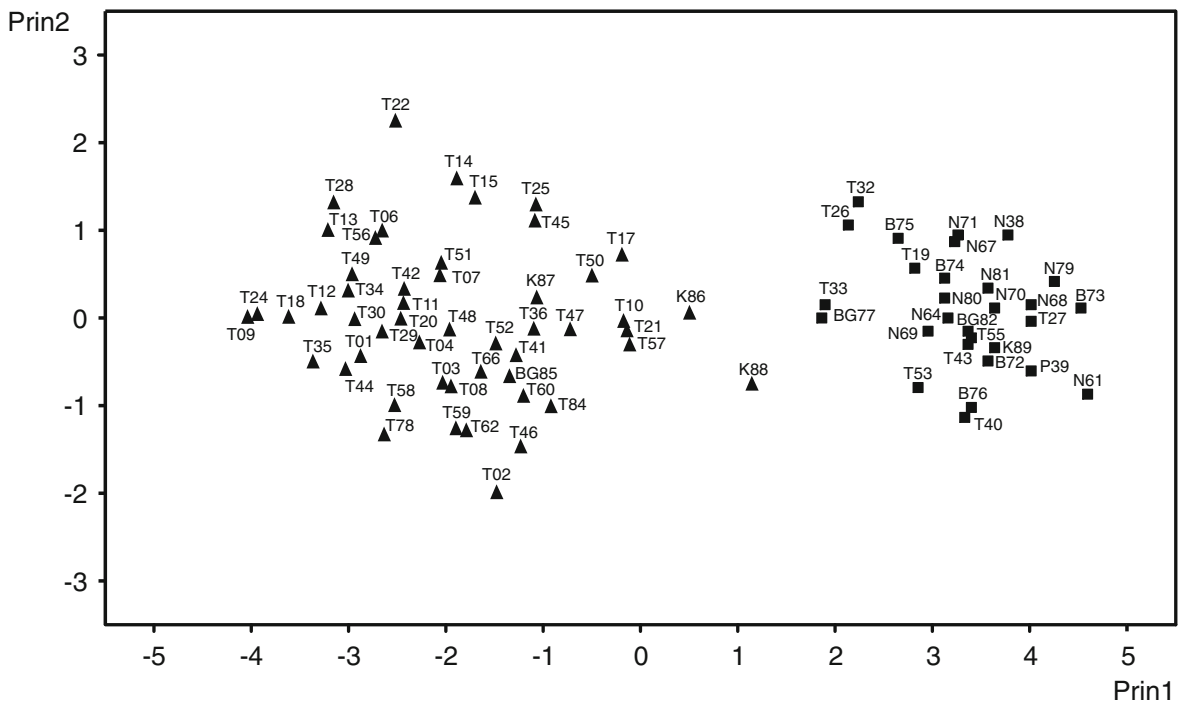

Fig. 3 PCA ordination graph of 80 populations of the Solidago virgaurea group based on 32 (a) and nine (b) morphological characters. The first two components explain $44.6 \%$ and $19.5 \%$ (a) and $80.9 \%$ and $6.7 \%$ (b) of the observed variation, respectively. Triangles - Solidago minuta, squares - Solidago virgaurea

shown on the right and $S$. minuta on the left of the diagrams. In the analysis based on 32 characters (Fig. 3a), the separation of the two population groups was not as clear as it was in the analysis based on nine characters (Fig. 3b). In PCA based on 32 characters, population K88 (Karkonosze Mts., 1,164 m a.s.1.), which in most cluster analyses was grouped in Group 2 (S. minuta), was resolved in a position among the populations of $S$. virgaurea, whereas population T26 (Tatra Mts., $947 \mathrm{~m}$ a.s.1.), which 
was grouped in Group 1 (S. virgaurea) in all cluster analyses, was resolved in a position close to the $S$. minuta populations (Fig. 3a). PCA ordination based on the subset of nine characters resulted in two distinct non-overlapping groupings (Fig. 3b), but one population (K88) lay between the two groups. The characters with the highest correlations (Table 2) with the first axis in the set of 32 characters were involucre height (InvH), number of tubular florets per capitulum (NTF) and inner involucral bract length $(\mathrm{BL})$. The characters with the highest correlations in the set of nine characters were involucre height ( $\mathrm{InvH})$, number of tubular florets per capitulum (NTF) and capitulum height $(\mathrm{CH})$.

In the PCA using individuals as objects, the plants from the two taxa formed two groupings; $S$. virgaurea is shown on the right and $S$. minuta on the left of the diagrams (Fig. 4a,b). The ordination of plants based on all 32 characters did not clearly separate the plant groupings within the two taxa, leaving a zone of overlap (Fig. 4a). However, the PCA based on nine capitulum and floret characters distinctly grouped the $S$. minuta and $S$. virgaurea plants, leaving only a very narrow overlap zone (Fig. 4b). The characters with the highest correlations (Table 2) with the first axis in the set of 32 characters were involucre height ( $\mathrm{InvH})$, number of shoot nodes (NSN), number of inflorescence branches having more than three capitula (NB3), number of tubular florets per capitulum (NTF), number of capitula per plant (NC) and plant height $(\mathrm{PH})$. The characters with the highest correlations with the first axis in the set of nine characters were the number of tubular florets per capitulum (NTF), involucre height (InvH), tubular floret length (TFL) and involucral bract length (BL).

The Pearson (parametric) and Spearman (non-parametric) correlation coefficients did not exceed 0.95 for any pair of characters in the entire dataset; therefore, all 32 quantitative characters were included in the subsequent discriminant analyses. The pair of characters for which the Pearson correlation coefficient exceeded 0.90 was ULL-ULLL (0.922); the Spearman correlation coefficient exceeded 0.90 for ULLULLL (0.925), NC-NCB (0.916), NCB-NB3 (0.916) and NC-NB3 (0.901) (see Table 1 for character abbreviations).

Canonical discriminant analysis based on individual plants demonstrated a strong separation between $S$. minuta and $S$. virgaurea (Fig. 5). The characters exhibiting the highest correlations with the canonical axis were the number of tubular florets (NTF), involucral bract width (WB), involucre height $(\mathrm{InvH})$ and capitulum height $(\mathrm{CH})$ (Table 2). A very high number of plants were correctly assigned to the corresponding taxa in the classificatory discriminant analysis. For S. minuta, 866 of 889 individuals (97.4\%) were correctly classified, and for S. virgaurea, 486 of 491 individuals $(99.0 \%)$ were correctly classified. Misclassified plants predefined in CDA as $S$. minuta originated from populations in the Tatra Mts. (T10, 1,159 m a.s.l., two plants; T17, 1,073 $\mathrm{m}$ a.s.1., four plants; T57, 1,165 $\mathrm{m}$ a.s.1., three plants; T47, 1,411 $\mathrm{m}$ a.s.1., two plants) and the Karkonosze Mts. (K88, 1,164 m a.s.1., 10 plants; K87, 1,257 $\mathrm{m}$ a.s.1., two plants). The misclassified $S$. virgaurea plants were from populations in the Tatra Mts. (T26, $947 \mathrm{~m}$ a.s.1., one plant; T43, $996 \mathrm{~m}$ a.s.1., one plant; T32, 1,318 m a.s.l., one plant) and on Mt. Babia Góra (BG77, $883 \mathrm{~m}$ a.s.l., two plants).

The means, standard deviations, minima, maxima, and the 10th and 90th percentiles for quantitative characters are presented in Table 3. Figure 6 shows the variation in characters with the highest contributions to separating S. minuta and S. virgaurea, as revealed by PCA and CDA. Although the minima and maxima of 
Table 2 Results of morphometric analyses of the Solidago virgaurea group

\begin{tabular}{|c|c|c|c|c|c|c|c|c|c|}
\hline & \multicolumn{2}{|c|}{ A (Fig. 3a) } & \multicolumn{2}{|c|}{ B (Fig. 3b) } & \multicolumn{2}{|c|}{ C (Fig. 4a) } & \multicolumn{2}{|c|}{ D (Fig. 4b) } & \multirow{2}{*}{$\begin{array}{c}\text { E (Fig. 5) } \\
\text { Can1 }\end{array}$} \\
\hline & Prin1 & Prin2 & Prin1 & Prin2 & Prin1 & Prin2 & Prin 1 & Prin2 & \\
\hline InvH & -0.240 & -0.075 & -0.380 & 0.131 & -0.262 & -0.097 & -0.351 & -0.075 & 0.472 \\
\hline $\mathrm{CH}$ & -0.218 & -0.078 & -0.357 & 0.164 & -0.239 & -0.099 & -0.325 & -0.221 & 0.402 \\
\hline NB & -0.220 & 0.031 & -0.319 & -0.492 & -0.208 & -0.011 & -0.332 & -0.345 & 0.373 \\
\hline NLF & -0.226 & -0.012 & -0.292 & -0.483 & -0.199 & -0.037 & -0.332 & -0.254 & 0.350 \\
\hline NTF & -0.240 & 0.031 & -0.363 & -0.351 & -0.249 & -0.011 & -0.355 & -0.185 & 0.587 \\
\hline $\mathrm{BL}$ & -0.236 & -0.069 & -0.346 & 0.189 & -0.237 & -0.097 & -0.341 & 0.067 & 0.372 \\
\hline BW & -0.229 & 0.115 & -0.337 & 0.115 & -0.238 & 0.028 & -0.335 & 0.253 & 0.514 \\
\hline TFL & -0.227 & -0.042 & -0.349 & 0.297 & -0.228 & -0.089 & -0.345 & 0.089 & 0.379 \\
\hline LW & -0.186 & 0.038 & -0.234 & 0.470 & -0.153 & -0.024 & -0.278 & 0.807 & 0.211 \\
\hline LFL & -0.211 & -0.181 & & & -0.209 & -0.141 & & & 0.278 \\
\hline LFW/LFL & 0.008 & 0.232 & & & 0.010 & 0.080 & & & 0.009 \\
\hline $\mathrm{BW} / \mathrm{BL}$ & -0.110 & 0.254 & & & -0.063 & 0.119 & & & 0.148 \\
\hline SL & -0.167 & -0.118 & & & -0.156 & -0.124 & & & 0.217 \\
\hline $\mathrm{PH}$ & 0.208 & -0.141 & & & 0.240 & -0.169 & & & -0.357 \\
\hline InfL & 0.159 & -0.179 & & & 0.152 & -0.287 & & & -0.164 \\
\hline InfL/PH & -0.099 & -0.102 & & & -0.091 & -0.215 & & & 0.136 \\
\hline $\mathrm{NSN}$ & 0.223 & -0.024 & & & 0.255 & -0.049 & & & -0.373 \\
\hline NB3 & 0.230 & -0.062 & & & 0.252 & -0.141 & & & -0.354 \\
\hline IBL & 0.195 & -0.098 & & & 0.177 & -0.224 & & & -0.181 \\
\hline IBL/InfL & 0.161 & 0.012 & & & 0.122 & -0.077 & & & -0.119 \\
\hline $\mathrm{NCB}$ & 0.228 & -0.067 & & & 0.230 & -0.176 & & & -0.303 \\
\hline $\mathrm{NC}$ & 0.223 & -0.050 & & & 0.241 & -0.158 & & & -0.300 \\
\hline MLL & -0.027 & -0.367 & & & -0.036 & -0.307 & & & -0.001 \\
\hline MLLL & 0.072 & -0.347 & & & 0.065 & -0.283 & & & -0.157 \\
\hline MLLW & 0.031 & -0.328 & & & 0.017 & -0.257 & & & -0.104 \\
\hline ULL & -0.137 & -0.312 & & & -0.134 & -0.338 & & & 0.149 \\
\hline ULLL & -0.096 & -0.356 & & & -0.095 & -0.348 & & & 0.088 \\
\hline ULLW & -0.111 & -0.322 & & & -0.113 & -0.312 & & & 0.105 \\
\hline ULL/InfL & -0.153 & 0.159 & & & -0.144 & 0.162 & & & 0.179 \\
\hline MLLW/MLLL & -0.093 & 0.000 & & & -0.072 & -0.001 & & & 0.060 \\
\hline ULLW/ULLL & -0.082 & -0.006 & & & -0.076 & -0.025 & & & 0.074 \\
\hline ULL/MLL & -0.165 & 0.002 & & & -0.135 & -0.113 & & & 0.196 \\
\hline
\end{tabular}

A, B - eigenvectors expressing correlations of 32 (A) and nine (B) measured characters with the principal component axes of PCA based on 80 population samples; C, D - eigenvectors expressing correlations of 32 (C) and nine (D) measured characters with the principal component axes of PCA based on 1,300 and 1,578 individuals, respectively; $\mathrm{E}$ - total canonical structure expressing correlations of the measured characters with the canonical axis. For character explanations, see Table 1.

all characters presented in Fig. 6 overlap considerably for the two taxa, the range of means \pm 1 standard deviation of most do not overlap at all. The involucres of $S$. minuta 
a

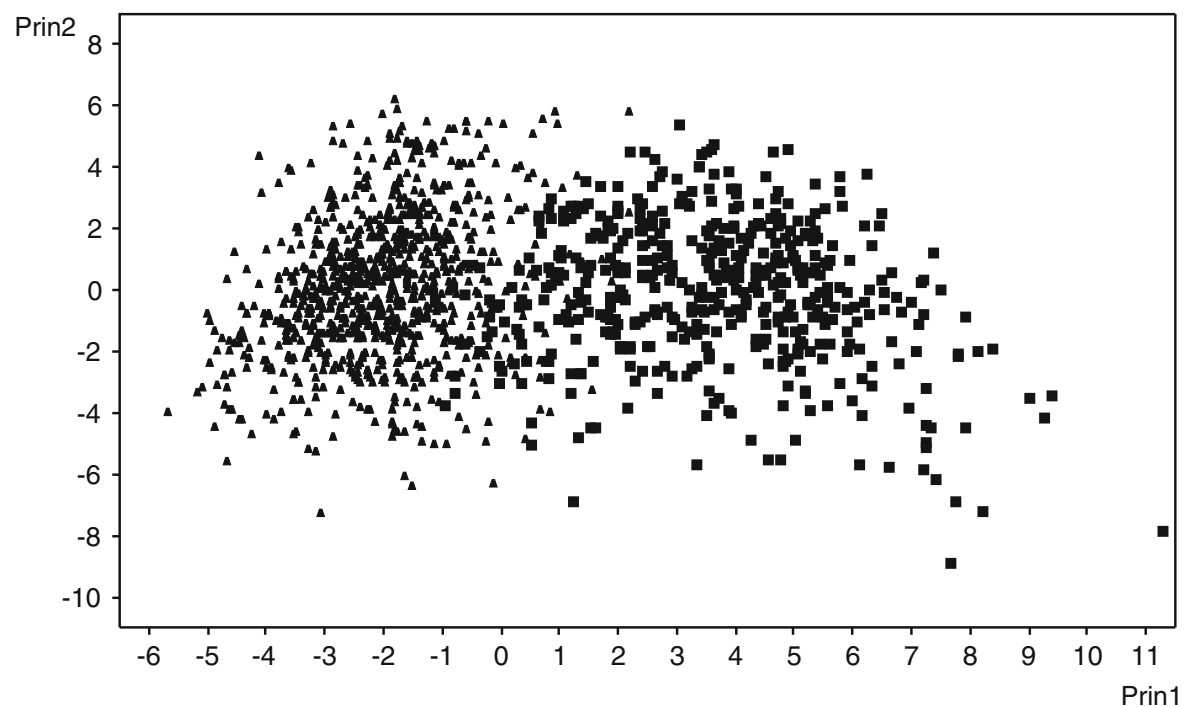

b

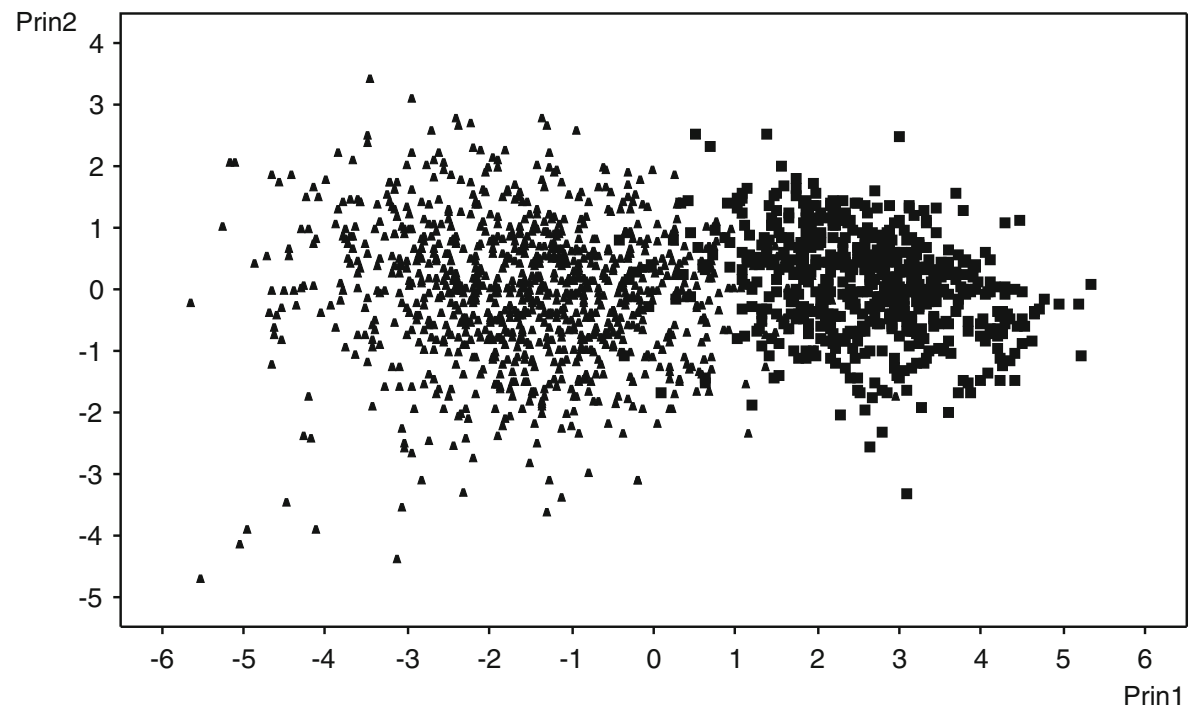

Fig. 4 PCA ordination graph of individuals of the Solidago virgaurea group based on 32 (a, 1,300 individuals) and nine (b, 1,578 individuals) morphological characters. The first two components explain $30.0 \%$ and $17.2 \%$ (a) and $60.1 \%$ and $12.0 \%$ (b) of the observed variation, respectively. Triangles Solidago minuta, squares - Solidago virgaurea

and $S$. virgaurea differ highly with respect to the number of rows formed by involucral bract apexes (semi-quantitative character DHB). The involucral bract apexes of $S$. minuta most often formed two $(86.1 \%)$ but rarely one $(5.2 \%)$ or three $(8.7 \%)$ rows whereas those from $S$. virgaurea formed mainly three $(79.4 \%)$ but rarely four $(14.7 \%)$ or two $(5.9 \%)$ rows. 


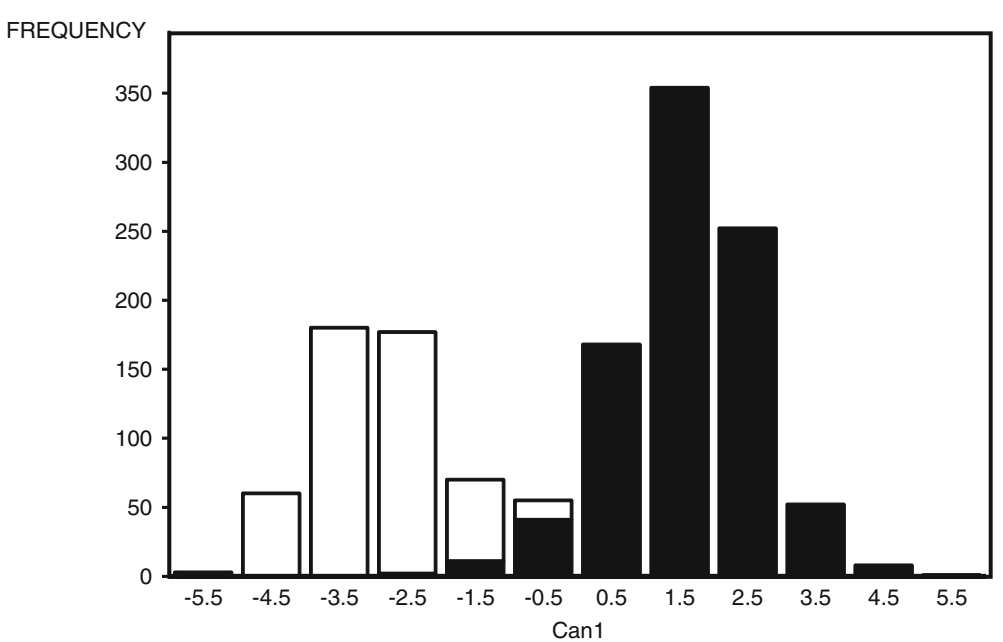

Fig. 5 CDA histogram of Solidago virgaurea (white) and Solidago minuta (black) individuals based on 32 morphological characters

\section{Common Garden Experiment}

Transplanted $S$. minuta and $S$. virgaurea plants were cultivated for three and four years in an experimental field in the lowlands; the results (Fig. 7) show that the differences in morphological characters between the two taxa are conspicuous and stable. Solidago minuta and S. virgaurea differed both in vegetative (Fig. 7a,b,c) and in capitulum and floret (Fig. 7d,e,f) characters. The phenotype of $S$. minuta grown under lowland conditions did not exhibit a tendency to change over the cultivation period.

\section{Discussion}

Our morphological analyses support the separation of two well-delimited and morphologically distinct taxa within the Solidago virgaurea group in Poland, which correspond well with the division of the group into lowland and high-mountain taxa in European floras. The most important characters for their division are the number of tubular florets per capitulum (NTF), involucral bract width (WB) and involucre height (InvH).

European floras and keys in which the high-mountain taxon is distinguished provide discriminative characters referring to the plant's habit and some characters of its capitula, involucre and florets. All the measured vegetative characters in this study described the typical lowland and high-mountain morphotypes but had less value than the capitulum characters for the identification of the two taxa. Cluster analyses and principal component analysis based on nine capitulum characters separated the groups of taxa more clearly than the analyses based on 32 characters, including many characters related to plant habit and leaves. The importance of capitulum and floret characters for delimiting the two taxa was confirmed in canonical discriminant analysis as performed for all 32 quantitative characters studied. 
Table 3 Mean (x), standard deviation (s.d.), minimum (min.), maximum (max.) and percentiles (10\%, $90 \%$ ) of quantitative characters used in morphometric analyses of the Solidago virgaurea group in Poland (upper row for $S$. minuta, lower for $S$. virgaurea)

\begin{tabular}{|c|c|c|c|c|c|c|}
\hline Character & $x$ & s.d. & $\min$ & $10 \%$ & $90 \%$ & $\max$ \\
\hline \multirow[t]{2}{*}{ Plant height - PH (mm) } & 337.2 & 121.32 & 60.0 & 175.0 & 490.0 & 760.0 \\
\hline & 622.2 & 253.17 & 125.0 & 310.0 & 970.0 & 1450.0 \\
\hline \multirow[t]{2}{*}{ Inflorescence length - InfL (mm) } & 144.3 & 76.04 & 8.0 & 50.0 & 245.0 & 420.0 \\
\hline & 219.5 & 123.25 & 25.0 & 80.0 & 380.0 & 780.0 \\
\hline \multirow[t]{2}{*}{ InfL/PH } & 0.42 & 0.1528 & 0.06 & 0.22 & 0.62 & 0.93 \\
\hline & 0.35 & 0.1209 & 0.09 & 0.20 & 0.51 & 0.83 \\
\hline \multirow[t]{2}{*}{ Number of shoot nodes - NSN } & 17.6 & 4.26 & 6 & 13 & 23 & 37 \\
\hline & 30.4 & 11.9 & 10 & 17 & 46 & 71 \\
\hline \multirow[t]{2}{*}{ Number of branches with more than 3 capitula } & 1.5 & 2.42 & 0 & 0 & 5 & 14 \\
\hline & 7.6 & 5.53 & 0 & 0 & 15 & 26 \\
\hline \multirow[t]{2}{*}{ Inflorescence branch length - IBL (mm) } & 40.3 & 30.14 & 1.0 & 13.0 & 75.0 & 235.0 \\
\hline & 90.1 & 85.59 & 10.0 & 20.0 & 220.0 & 590.0 \\
\hline \multirow[t]{2}{*}{ IBL/InfL } & 0.28 & 0.1302 & 0.04 & 0.15 & 0.46 & 1.00 \\
\hline & 0.38 & 0.2120 & 0.07 & 0.15 & 0.70 & 1.12 \\
\hline \multirow[t]{2}{*}{ Number of capitula per plant $-\mathrm{NC}$} & 24.7 & 18.35 & 2 & 8 & 46 & 174 \\
\hline & 100.6 & 92.16 & 5 & 20 & 202 & 762 \\
\hline \multirow[t]{2}{*}{ Number of capitula per single branch - NCB } & 3.4 & 2.62 & 1 & 1 & 6 & 21 \\
\hline & 13.1 & 12.07 & 1 & 3 & 27 & 144 \\
\hline \multirow[t]{2}{*}{ Capitulum stalk length - SL (mm) } & 13.0 & 7.38 & 1.0 & 6.0 & 23.0 & 60.0 \\
\hline & 6.9 & 2.94 & 2.0 & 4.0 & 11.0 & 22.0 \\
\hline \multirow[t]{2}{*}{ Capitulum height - $\mathrm{CH}(\mathrm{mm})$} & 9.1 & 1.15 & 6.5 & 8.0 & 10.5 & 14.0 \\
\hline & 7.2 & 0.76 & 5.0 & 6.0 & 8.0 & 10.0 \\
\hline \multirow[t]{2}{*}{ Involucre height - InvH (mm) } & 7.4 & 0.88 & 4.5 & 6.5 & 8.5 & 10.0 \\
\hline & 5.7 & 0.71 & 4.0 & 5.0 & 6.5 & 7.5 \\
\hline \multirow[t]{2}{*}{ Number of involucral bracts per capitulum - NB } & 23.5 & 3.56 & 15 & 19 & 28 & 40 \\
\hline & 17.9 & 2.76 & 11 & 15 & 22 & 30 \\
\hline \multirow[t]{2}{*}{ Inner involucral bract length - BL (mm) } & 7.1 & 0.92 & 4.0 & 6.0 & 8.3 & 10.5 \\
\hline & 5.7 & 0.76 & 3.7 & 4.7 & 6.7 & 7.8 \\
\hline \multirow[t]{2}{*}{ Inner involucral bract width BW (mm) } & 1.5 & 0.23 & 1.0 & 1.3 & 1.8 & 2.5 \\
\hline & 1.1 & 0.15 & 0.7 & 0.9 & 1.3 & 1.6 \\
\hline \multirow[t]{2}{*}{ Number of ligulate florets per capitulum - NLF } & 11.0 & 2.13 & 5 & 8 & 14 & 20 \\
\hline & 8.1 & 1.55 & 5 & 6 & 10 & 13 \\
\hline \multirow[t]{2}{*}{ Number of tubular florets per capitulum - NTF } & 28.4 & 6.20 & 11 & 21 & 36 & 64 \\
\hline & 14.4 & 2.94 & 5 & 11 & 18 & 26 \\
\hline \multirow[t]{2}{*}{ Ligulate floret length - LFL (mm) } & 9.8 & 1.22 & 6.0 & 8.3 & 11.4 & 14.1 \\
\hline & 8.3 & 1.05 & 5.4 & 7.1 & 9.7 & 12.3 \\
\hline \multirow[t]{2}{*}{ Ligule width - LW (mm) } & 1.8 & 0.31 & 0.9 & 1.5 & 2.2 & 3.0 \\
\hline & 1.5 & 0.27 & 0.9 & 1.2 & 1.9 & 2.5 \\
\hline \multirow[t]{2}{*}{ Tubular floret length - TFL (mm) } & 6.6 & 0.57 & 4.8 & 5.9 & 7.3 & 9.0 \\
\hline & 5.6 & 0.51 & 3.6 & 5.0 & 6.3 & 7.1 \\
\hline
\end{tabular}


Table 3 (continued)

\begin{tabular}{lcccccc}
\hline Character & $x$ & s.d. & min. & $10 \%$ & $90 \%$ & max. \\
\hline BW/BL & 0.22 & 0.0410 & 0.12 & 0.17 & 0.27 & 0.39 \\
& 0.19 & 0.0365 & 0.11 & 0.15 & 0.24 & 0.37 \\
LW/LFL & 0.19 & 0.0378 & 0.08 & 0.14 & 0.24 & 0.38 \\
& 0.19 & 0.0364 & 0.10 & 0.14 & 0.23 & 0.31 \\
Middle stem leaf length - MLL (mm) & 117.4 & 31.33 & 30.0 & 76.0 & 155.0 & 217.0 \\
& 116.5 & 33.86 & 45.0 & 73.0 & 161.0 & 225.0 \\
Middle stem leaf lamina length - MLLL (mm) & 71.0 & 21.57 & 17.0 & 45.0 & 100.0 & 155.0 \\
& 85.9 & 25.28 & 30.0 & 52.0 & 120.0 & 185.0 \\
Middle stem leaf lamina width - MLLW (mm) & 22.5 & 7.44 & 4.0 & 14.0 & 32.0 & 62.0 \\
& 25.9 & 9.52 & 7.0 & 14.0 & 40.0 & 60.0 \\
MLLW/MLLL & 0.32 & 0.0624 & 0.03 & 0.24 & 0.40 & 0.69 \\
Upper stem leaf length - ULL (mm) & 0.30 & 0.0700 & 0.13 & 0.21 & 0.40 & 0.53 \\
Upper stem leaf lamina length - ULLL (mm) & 83.2 & 25.87 & 20.0 & 50.0 & 117.0 & 190.0 \\
& 67.0 & 23.06 & 20.0 & 39.0 & 97.0 & 162.0 \\
Upper stem leaf lamina width - ULLW (mm) & 66.3 & 20.21 & 12.0 & 40.0 & 92.0 & 165.0 \\
& 58.1 & 20.53 & 17.0 & 34.0 & 86.0 & 127.0 \\
ULLW/ULLL & 18.9 & 6.29 & 3.0 & 12.0 & 27.0 & 44.0 \\
ULL/InfL & 15.9 & 7.29 & 3.0 & 8.0 & 26.0 & 46.0 \\
ULL/MLL & 0.29 & 0.0586 & 0.11 & 0.22 & 0.36 & 0.61 \\
& 0.27 & 0.0722 & 0.10 & 0.18 & 0.36 & 0.53 \\
& 0.74 & 0.4650 & 0.16 & 0.39 & 1.16 & 6.62 \\
& 0.41 & 0.2773 & 0.09 & 0.15 & 0.80 & 1.63 \\
& 0.73 & 0.1568 & 0.24 & 0.52 & 0.93 & 1.4 \\
& 0.59 & 0.1547 & 0.17 & 0.38 & 0.79 & 1.1 \\
\hline & & & & & & \\
& & & & & \\
& & &
\end{tabular}

Numerical analyses also revealed that morphologically intermediate forms exist between $S$. minuta and $S$. virgaurea. This was shown in the cluster analyses in which, depending on the algorithm employed (UPGMA, Ward method), populations T10 (Tatra Mts., 1,159 m a.s.1.) and K88 (Karkonosze Mts., 1,164 m a.s.l.) were classified differently. The different classification of population K86 (Karkonosze Mts., 1,404 m a.s.1.) was most likely explained by the small capitula of plants growing at the high altitudes of the Sudetes. The existence of intermediate plants was also suggested by the overlapping of plants in the PCA ordination diagrams and in the CDA histogram. However, the zone in which plants of the two taxa overlapped by morphology was relatively narrow and did not obscure the separation of two well-defined groups.

In the Flora Europaea, the author of the genus Solidago (McNeill 1976) did not clearly distinguish between high-mountain and lowland taxa. McNeill presented a morphological description and the values of some quantitative characters for $S$. virgaurea sensu lato but provided values for only two of them (stem height and involucre height) for subsp. minuta, which were completely within the range of variation of $S$. virgaurea s.l., making it impossible to identify lowland and high-mountain taxa on that basis. 
a

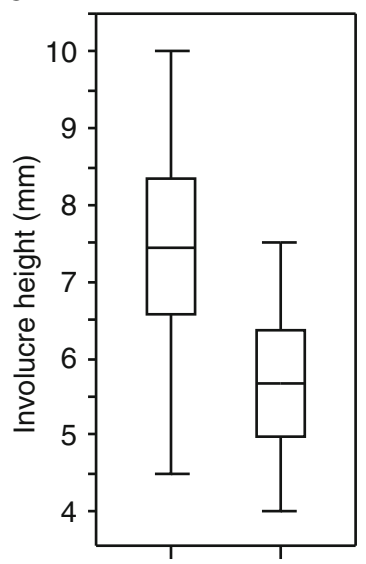

d

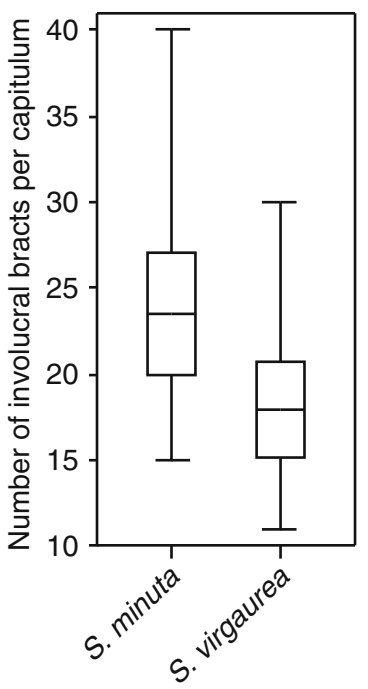

b

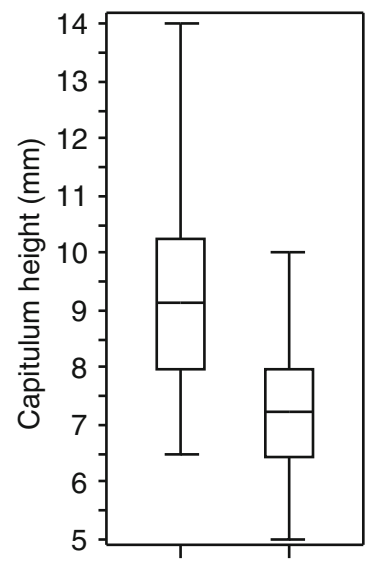

e

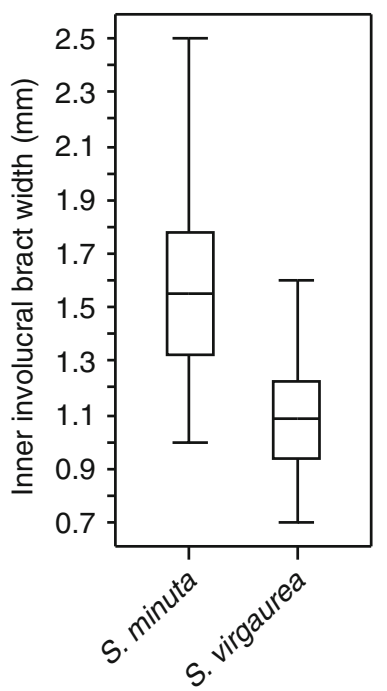

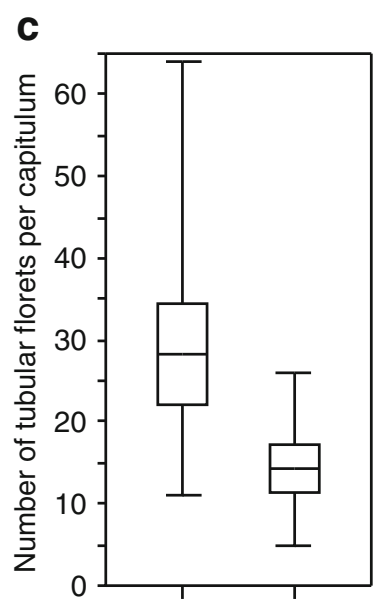

f

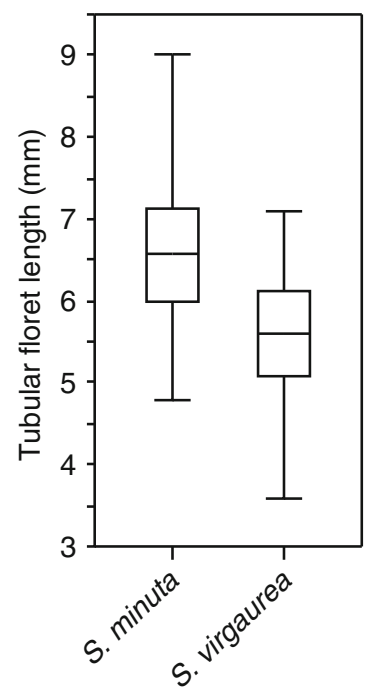

Fig. 6 Variation of selected morphological characters in Solidago minuta $(N=1128)$ and Solidago virgaurea $(N=618)$. Horizontal lines represent means, rectangles define means \pm 1 standard deviation, and whiskers represent minima and maxima

One of the characters distinguishing the high-mountain from the lowland taxon of the $S$. virgaurea group is capitulum size. This character was noted in the first description of the high-mountain morphotype (Virga Aurea Omnium minima Floribus maximis, in Hermann 1698) and was subsequently repeated in floras and keys. The character was later quantitatively expressed as capitulum diameter, which was measured to be $10-15 \mathrm{~mm}$ for the lowland and $15-20 \mathrm{~mm}$ for the high-mountain taxon (Hess et al. 1972; Dostál 1989; Rothmaler 1994; Slavík 2004). In this work, however, the capitulum size is expressed as the number of florets, a character not biased by herbarium specimen pressing and one that is widely used in taxonomic works on the genus Solidago (e.g., Weber 1997; Nishizawa et al. 2001) and on other taxa from the 

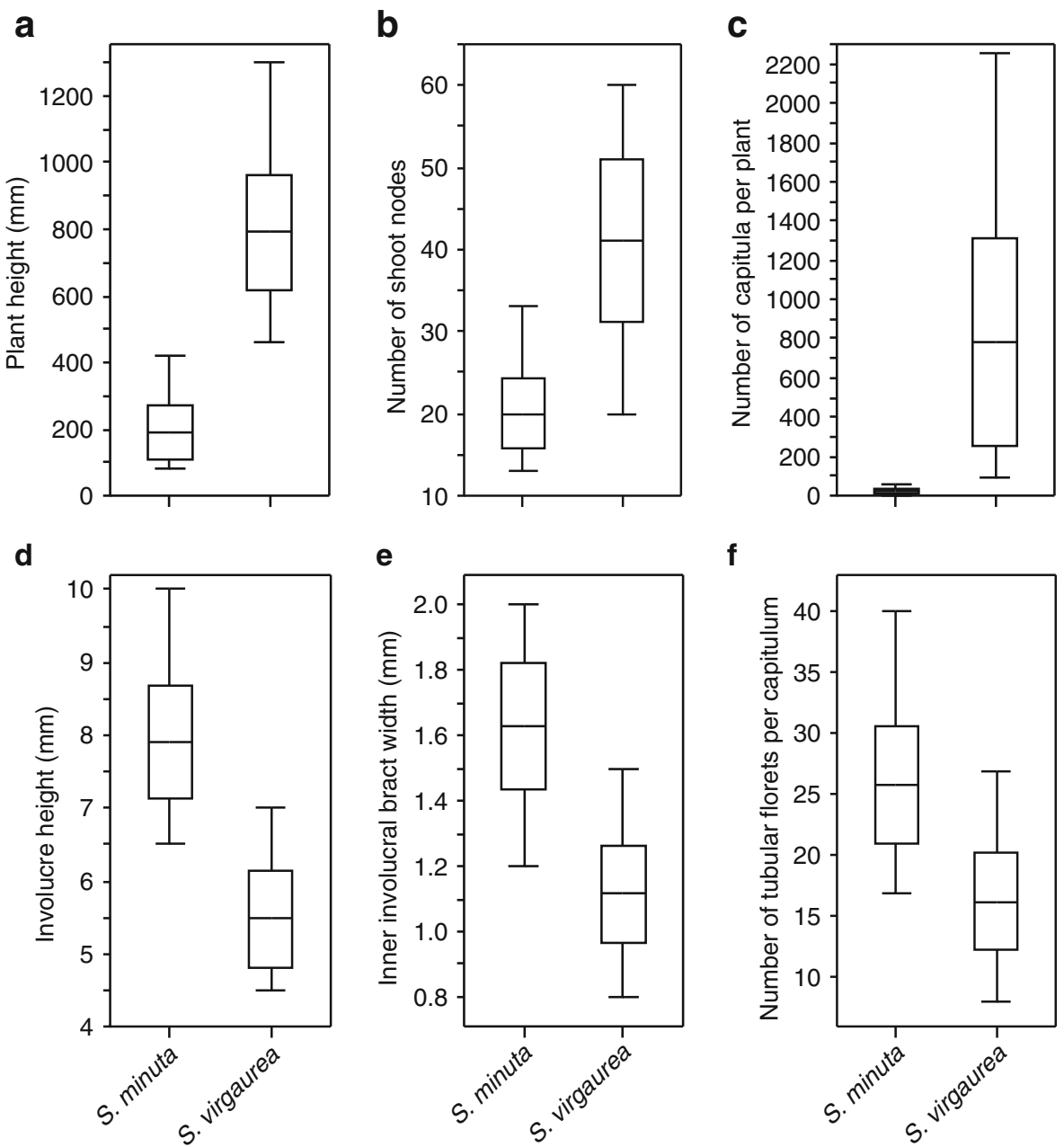

Fig. 7 Variation of selected morphological characters of Solidago minuta $(N=62)$ and Solidago virgaurea $(N=47)$ cultivated in an experimental field in the lowlands. Horizontal lines represent means, rectangles define the means \pm 1 standard deviation, and whiskers represent minima and maxima

Asteraceae family (e.g., Hodálová 1999; Španiel et al. 2008). Our results show that $S$. minuta has considerably more florets than $S$. virgaurea, especially tubular florets (Table 3, key below).

Another important character for expressing capitulum size as given in some European floras for discriminating between $S$. virgaurea and $S$. minuta is involucre height; for the lowland and high-mountain taxa, these were determined to be (4.5) 5$7 \mathrm{~mm}$ and 7-9 (10) mm, respectively (Rostański 1971; Hess et al. 1972; Wagenitz 1979; Slavík 2004). Our results approximately match these values (Table 3). The range overlap of involucre height for the two taxa is partly due to the small size of the capitula of some S. minuta plants growing in the Tatra Mts. at elevations greater than 2,000 $\mathrm{m}$ a.s.1.

The results of our morphometric study differ from data presented by Slavík (2004) in the Flora of the Czech Republic. The discrepancies concern morphological characters of 
the capitulum, that is, the number of involucral bracts and the numbers of ligulate and tubular florets. For subsp. virgaurea, Slavík reports approximately 30 involucral bracts per involucre, most often 13 ligulate florets per capitulum and approximately 30 tubular florets per capitulum; for subsp. minuta the reported values are 18-22 involucral bracts, 11 ligulate florets and 26 tubular florets. The values we noted most frequently (modes) were 17 involucral bracts, 8 ligulate florets and 14 tubular florets for $S$. virgaurea, and 24 involucral bracts, 11 ligulate florets and 26 tubular florets for S. minuta. These differences are important because they concern diagnostic characters. Because the tubular and ligulate florets do not differ greatly in size between $S$. virgaurea and S. minuta, the data presented by Slavík (2004) appear to imply that the lowland taxon has a capitulum slightly larger or equal in size to that of the high-mountain taxon. This, however, would contradict not only our results but also the data presented in many European floras (mentioned above) and in the Flora of the Czech Republic (Slavík 2004). Morphometric revision of the plant material of the $S$. virgaurea group from the Czech Republic is required to clarify this issue.

It is worth noting that Nishizawa et al. (2001) found analogous morphological patterns for other taxa of the Solidago virgaurea complex along an elevation gradient in Japan, that is, lowland $S$. virgaurea subsp. asiatica Kitam. and high-mountain S. virgaurea subsp. leiocarpa (Benth.) Hultén. The high-mountain taxon exhibited a greater number of tubular florets per capitulum than the lowland taxon, and the number of tubular florets per capitulum was found to be an important diagnostic character for the lowland and high-mountain taxa.

Although not used in numerical analyses, the differentiation of involucral bract height (DHB), a semi-quantitative character of the capitulum, proved useful for identifying taxa. The values we obtained for this character in S. virgaurea and S. minuta (see Results) agree with the characteristics given by Wagenitz (1979).

We did not use the morphological characters of the basal and lowest stem leaves in this study, which had previously been used to distinguish the two taxa (Rostański 1971) because they are already wilted at the flowering stage. In our material, basal leaves were present only in $22 \%$ of the specimens, and the lowest stem leaves were present in $41 \%$.

During three and four years of the $S$. minuta and $S$. virgaurea cultivation in the lowland plot, both taxa showed stable phenotypes, which must therefore have a genetic background. None of the observed morphological characters in S. minuta that were transplanted from high-mountain altitudes to the lowlands changed during the cultivation period. In cultivating transplanted $S$. minuta, we allowed for the possibility that high-mountain plants exhibit floral preformation; that is, buds may be formed underground one, two or even three years before starting their development (Billings 1974; Körner 2003). The very longest preformation period was reported to be four years in Polygonum viviparum (Diggle 1997). Assessing the characters of plants grown in lowland conditions from buds formed previously in an alpine environment may be a potential source of methodological error. To rule out this possibility, we extended the cultivation period to four years for some populations. During cultivation, the plants of both taxa also exhibited differences in phenology. The flowering of $S$. minuta lasted for approximately one month from mid-May to mid-June and that of $S$. virgaurea from the lowlands lasted approximately two months from mid-July to mid-September. However, S. virgaurea plants 
transplanted from low altitudes in the Tatra Mts. (populations T19, $942 \mathrm{~m}$ a.s.l. and T53, $965 \mathrm{~m}$ a.s.1.) flowered during a time that was intermediate between those of lowland $S$. virgaurea and $S$. minuta, starting approximately in mid-June and ending at the beginning of August.

Altitudinal vicariance exhibits a different pattern in different taxa groups. For example, Marhold (1992) found in Cardamine amara from the Carpathians and Sudetes that lowland-lower montane $C$. amara subsp. amara is replaced in the mountains by subalpine-upper montane $C$. amara subsp. opicii with an overlap zone at the altitude of $850-1,350 \mathrm{~m}$ a.s.l.; in this group, intermediate types besides the typical morphotypes were also frequently noted. In the Caltha palustris- $C$. laeta pair, Cieślak (2004) found that lowland C. palustris reached an altitude of 1,300 m a.s.l. in the Carpathians whereas mountain $C$. laeta descended from the subalpine and alpine belts to $300 \mathrm{~m}$ a.s.l. in the lowlands; therefore, the two taxa have a very wide altitudinal zone of common occurrence. Filipová and Krahulec (2006) found in the pair of Anthoxanthum odoratum-A. alpinum in the Karkonosze Mts. (Sudetes) that lowland-lower montane $A$. odoratum and subalpine-alpine A. alpinum overlap at 900-1,290 m a.s.1., but A. alpinum was found to descend in favourable habitats to as low as $750 \mathrm{~m}$ a.s.1. In the Solidago virgaurea group, lowland $S$. virgaurea stays in mountains mainly in the lower montane belt and occasionally reaches lower elevations of the upper montane belt (1,337 $\mathrm{m}$ a.s.1. in the Bieszczady Mts., 1,318 $\mathrm{m}$ a.s.1. in the Tatra Mts.); Solidago minuta, the range of which is above the timber line in the subalpine and alpine belts, descends to the upper montane belt and rarely to the upper part of the lower montane belt (1,073 m a.s.l. in the Tatra Mts.). Thus, the zone of altitudinal overlap for $S$. virgaurea and $S$. minuta is quite narrow. According to a classification of vascular plant altitudinal ranges in the Carpathians (Mirek 1989), $S$. virgaurea can be classified as lowland-lower montane, and S. minuta classified as subalpine-alpine. For all pairs of altitudinal vicariants mentioned above, the common pattern is that lowland taxa reach the lower montane belt or lower elevations of the upper montane belt. Thus, the width of the overlap zone depends mainly on the altitudinal ranges of the alpine taxa.

In this work we adopted and consistently applied a species rank for $S$. virgaurea and $S$. minuta by following their author, Linnaeus. We share the view of Porter (1893) that the divergence between lowland $S$. virgaurea and $S$. minuta (noted there as $S$. alpestris) "is so wide that it may be well counted a good species". In our opinion, the differences between $S$. virgaurea and $S$. minuta, with their many morphological characters, phenology, different distributions along the altitudinal gradient and related differences in occupied habitats, fully justify treating them as separate species. All of the morphological characters that we studied in the two taxa proved to be stable in cultivation. Typical Solidago virgaurea and $S$. minuta plants have very different habits, which are not related to the effects of species plasticity (ecological modifications) but must have a genetic background. The existence of intermediate populations between $S$. virgaurea and $S$. minuta in the contact zone of the two taxa, which are most likely the result of hybridisation, did not prevent us from distinguishing morphologically distinct taxa. This acknowledgment does not constitute a case against treating taxa at the species level, as for example, in the Senecio nemorensis group (cf. Hodálová and Marhold 1998; Hodálová 1999). 


\section{Key to the Species of the Solidago virgaurea Group Occurring in Poland}

Character values given in the key represent 10th and 90th percentiles; those in parentheses represent minima and maxima.

1a Number of tubular florets per capitulum (5-)11-18(-26), involucre height (4.0-)5.0$6.5(-7.5) \mathrm{mm}$, involucral bract width $(0.7-) 0.9-1.3(-1.6) \mathrm{mm}$, capitulum height $(5.0-) 6.0-8.0(-10.0) \mathrm{mm}$, number of involucral bracts per capitulum (11-)15$22(-30)$, tubular floret length (3.6-)5.0-6.3(-7.1) mm, most often bract apexes form at involucre three or four rows .......................... Solidago virgaurea

1b Number of tubular florets per capitulum (11-)21-36(-64), involucre height (4.5-)6.5-8.5(-10.0) mm, involucral bract width (1.0-) $1.3-1.8(-2.5) \mathrm{mm}$, capitulum height $(6.5-) 8.0-10.5(-14.0) \mathrm{mm}$, number of involucral bracts per capitulum (15-)19-28(-40), tubular floret length (4.8-)5.9-7.3(-9.0) mm, most often bract apexes form at involucre two rows ................. Solidago minuta

Acknowledgements We are grateful to Wiesława Kiełtyk (Warsaw) for her assistance with data collection and for helping us establish and maintain the experimental plot. We wish to express our thanks to Karol Marhold (Bratislava, Praha) and two anonymous reviewers for their valuable comments on the manuscript. We thank to the authorities of the following Polish national parks for permission to collect material: Babia Góra NP, Bieszczady NP, Karkonosze NP, Pieniny NP and Tatra NP. This study was financially supported by the Grant Agency of the Polish Ministry of Science and Higher Education in 2006-2009 (grant No. N303 028 31/0845).

Open Access This article is distributed under the terms of the Creative Commons Attribution License which permits any use, distribution, and reproduction in any medium, provided the original author(s) and the source are credited.

\section{References}

Billings WD (1974) Arctic and alpine vegetation: plant adaptation to cold summer climates. In Ives JD, Barry RG (eds) Arctic and alpine environments. Methuen, London, pp 403-443

Cieślak E (2004) Morphological variability of the Caltha palustris L. complex (Ranunculaceae) in Poland. Acta Soc Bot Poloniae 73:193-201

Diggle PK (1997) Extreme preformation in alpine Polygonum viviparum: an architectural and developmental analysis. Amer J Bot 84:154-169

Dostál J (1989) Nová Květena ČSSR 2 (New Flora of the Czechoslovak Socialistic Republic 2). Academia, Praha

Filipová L, Krahulec F (2006) The transition zone between Anthoxanthum alpinum and A. odoratum in the Krkonoše Mts. Preslia 78:317-330

Flegrová M, Krahulec F (1999) Anthoxanthum odoratum and A. alpinum: life history parameters at two different altitudes. Folia Geobot 34:19-31

Greuter W (2006-2009) Compositae (pro parte majore). In Greuter W, Raab-Straube E (eds) Compositae. Euro + Med Plantbase - the information resource for Euro-Mediterranean plant diversity. Available at: http://ww2.bgbm.org/EuroPlusMed/ [accessed 3.07.2012]

Hermann P (1698) Paradisus batavus. Abraham Elzevier, Lugduni-Batavorum

Hess HE, Landolt E, Hirzel R (1972) Flora der Schweiz und angrenzender Gebiete 3: Plumbaginaceae bis Compositae. Birkhäuser, Basel, Stuttgart

Hodálová I (1999) Multivariate analysis of the Senecio nemorensis group (Compositae) in the Carpathians with a new species from the East Carpathians. Folia Geobot 34:321-335

Hodálová I, Marhold K (1998) Morphometric comparison of Senecio germanicus and S. nemorensis (Compositae) with a new species from Romania. Bot J Linn Soc 128:277-290 
Hodálová I, Mered’a P Jr, Mártonfi P, Mártonfiová L, Danihelka J (2008) Morphological characters useful for the delimitation of taxa within Viola subsect. Viola (Violaceae): a morphometric study from the West Carpathians. Folia Geobot 43:83-117

Hultén E, Fries M (1986) Atlas of North European vascular plants north of the Tropic of Cancer. 2. Koeltz Scientific Books, Königstein

Jarvis ChE, Turland NJ (1998) Typification of Linnean specific and varietal names in the Compositae (Asteraceae). Taxon 47:347-370

Kereguélen M (1999) Index synonymique de la flore de France. Available at: http://www2.dijon.inra.fr/bga/ fdf/index.htm [accessed 3.07.2012]

Klecka WR (1980) Discriminant analysis. Sage University Papers, Series: Quantitative applications in the social sciences, no. 19, Sage, Beverly Hills, London

Körner Ch (2003) Alpine plant life. Functional plant ecology of high mountain ecosystems. Springer, Berlin, Heidelberg

Korobkov AA (2012) Asteraceae. In Elven R (ed) Annotated Checklist of the Panarctic Flora (PAF) vascular plants. Available at: http://nhm2.uio.no/paf/ [accessed 3.07.2012]

Krahulec F, Marhold K, Schmid B (1999) Ecology of closely related plant species: an introduction. Folia Geobot 34:1-5

Legendre P, Legendre L (1998) Numerical ecology. Elsevier Science, Amsterdam

Letz R, Marhold K (1998) Multivariate morphometric study of the Sempervivum montanum group (Crassulaceae) in the West Carpathians. Phyton (Horn) 38:323-336

Linnaeus C (1753) Species plantarum. Ed. 1. Impensis Laurentii Salvii, Stockholm

Linnaeus C (1762-1763) Species plantarum. Ed. 2. Impensis Laurentii Salvii, Stockholm

Marhold K (1992) A multivariate morphometric study of the Cardamine amara group (Cruciferae) in the Carpathian and Sudeten mountains. Bot J Linn Soc 110:121-135

Marhold K, Goliašová K, Hegedüšová Z, Hodálová I, Jurkovičová V, Kmet’ová E, Letz R, Michalková E, Mráz P, Peniašteková M, Šípošová H, Ťavoda O (1998) Ferns and flowering plants. In Marhold K, Hindák F (eds) Checklist of non-vascular and vascular plants of Slovakia, VEDA, Bratislava. Available at: http://ibot.sav.sk/checklist/ [accessed 17.07.2012]

Marhold K, Mártonfi P, Mered’a P Jr, Mráz P, Hodálová I, Kolník M, Kučera J, Lihová J, Mrázová V, Perný M, Valko I (2007) Chromosome number survey of the ferns and flowering plants of Slovakia. VEDA, Bratislava. Available at: http://www.chromosomes.sav.sk [accessed 17.07.2012]

McNeill J (1976) Solidago L. In Tutin TG, Heywood VH, Burges NA, Moore DM, Valentine DH, Walters SM, Webb DA (eds) Flora Europaea 4. Cambridge University Press, London, New York, pp 110-111

Meusel H, Jäger EJ (1992) Vergleichende Chorologie der zentraleuropäischen Flora 3. G. Fischer, Jena, Stuttgart, New York

Mirek Z (1989) Zasięgi wysokościowe roślin naczyniowych w Karpatach i ich klasyfikacja (Altitudinal ranges of vascular plants in the Carpathians and their classification). Wiadom Bot 33:57-64

Nishizawa T, Kinoshita E, Yakura K, Shimizu T (2001) Morphological variation of the head characters in Solidago virgaurea L. inhabiting three mountains in central Honshu. J Phytogeogr Taxon 49:117-127

Pitschmann H, Reisigl H (1965) Flora der Südalpen vom Gardasee zum Comersee. Ed. 2. G. Fischer, Stuttgart

Podani J (2000) Introduction to the exploration of multivariate biological data. Backhuys, Leiden

Porter TC (1893) Solidago humilis Pursh of eastern states and its allies. Bull Torrey Bot Club 20:207211

Rebristaya OV (1987) Solidago L. - zolotarnik, zolotaya rozga. In Yurtsev BA (ed) Arkticheskaya flora SSSR. Kriticheskii obzor sosudistykh rastenii vstrechayushchikhsya v arkticheskikh raionakh SSSR 10, Semeistva Rubiaceae - Compositae (Arctic flora of the USSR. Critical account of vascular plants occurring in the arctic regions of the USSR 10, Families Rubiaceae-Compositae). Izdatel'stvo Nauka, Leningradskoe otdelenie, Leningrad, pp 63-67

Rostański K (1971) Solidago L. In Pawłowski B, Jasiewicz A (eds) Flora Polska. Rośliny naczyniowe Polski $i$ ziem ościennych 12 (Flora of Poland. Vascular plants of Poland and adjacent territories). Państwowe Wydawnictwo Naukowe, Warszawa, Kraków, pp 116-122

Rothmaler W (1994) Exkursionflora von Deutschland 4 Gefässpflanzen: Kritischer Band. G. Fischer, Jena, Stuttgart

Skalińska M, Pogan E, Czapik R (1978) Further studies in chromosome numbers of Polish Angiosperms. Twelfth contribution. Acta Biol Cracov, Ser Bot 21:31-63

Skawińska K (1981) Analiza biometryczna wybranych cech morfologicznych Solidago virgaurea L. (Biometrical analysis of some morphological characters of Solidago virgaurea L.). Fragm Florist Geobot 27:331-341 
Slavík B (2004) Solidago L. - zlatobýl. In Slavík B, Štěpánková J (eds) Květena České Republiky 7 (Flora of the Czech Republic 7). Academia, Praha, pp 114-123

Sneath PHA, Sokal RR (1973) Numerical taxonomy. The principles and practice of numerical classification. W.H. Freeman and Company, San Francisco

Španiel S, Marhold K, Hodálová I, Lihová J (2008) Diploid and tetraploid cytotypes of Centaurea stoebe (Asteraceae) in Central Europe: morphological differentiation and cytotype distribution patterns. Folia Geobot 43:131-158

Španiel S, Marhold K, Filová B, Zozomová-Lihová J (2011) Genetic and morphological variation in the diploid-polyploid Alyssum montanum in Central Europe: taxonomic and evolutionary considerations. Pl Syst Evol 294:1-25

StatSoft Inc. (2004) Statistica - data analysis software system, version 7. Tulsa, OK

Szafer W, Kulczyński S, Pawłowski B (1976) Rośliny polskie (Polish plants). Państwowe Wydawnictwo Naukowe, Warszawa

Szymkiewicz D (1929) Études biométriques sur Solidago Virga aurea. Acta Soc Bot Poloniae 6:341-343 Wagenitz G (1979) Compositae I: Allgemeine Teil, Eupatorium - Achillea. In Conert HJ, Hamann W, Schultze-Motel W, Wagenitz G (eds) Hegi Illustierte Flora von Mitteleuropa Band 4, Teil 3. Parey Bucherverlag, Berlin, pp 16-32

Weber E (1997) Morphological variation of the introduced perennial Solidago canadensis L. sensu lato (Asteraceae) in Europe. Bot J Linn Soc 123:197-210

Yuzepchuk SV (1959) Zolotarnik - Solidago L. In Shishkin BK (ed) Flora SSSR 25. Izdatel'stvo Akademii Nauk SSSR, Moskva, Leningrad, pp 31-50

Zar JH (2010) Biostatistical analysis. Ed. 5, Prentice Hall, New Jersey

Received: 10 January 2012 / Revised: 7 June 2013 / Accepted: 26 June 2013 /

Published online: 12 November 2013

Appendix 1 List of localities of the population samples. Records are given as follows: population code, locality description, geographic coordinates (WGS84), altitude and number of plants used for morphometric analyses in brackets. "trans" indicates populations from which plants were transplanted to the experimental field.

\section{Solidago virgaurea $\mathrm{L}$.}

B72 - Bieszczady Mts., near side of road between Cisna and Wola Michowa villages, $49^{\circ} 12^{\prime} 59.3^{\prime \prime} \mathrm{N}, 022^{\circ} 14^{\prime} 03.3^{\prime \prime}$ E, 662 m, (25), trans; B73 - Bieszczady Mts., Tarnica peak, 4904'30.0" N, 022 43'34.6" E, 1,337 m (11); B74 -

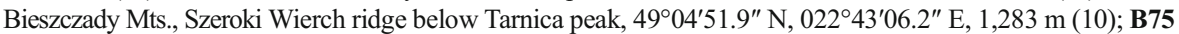

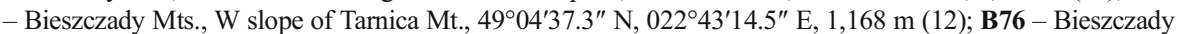
Mts., forest on SW slope above Wołosate village, 4904'05.9" N, 022 41'49.4" E, 838 m (7); BG77 - Babia Góra Mt., Przełęcz Krowiarki pass, 49³6'04.6" N, 019³4'28.5" E, 883 m (23); BG82 - Babia Góra Mt., forest above Zawoja-Markowa village, 49³6'20.0" N, 019³1'11.4" E, 730 m (25); K89 - Karkonosze Mts., forest in town of Karpacz, 50 46 $35.3^{\prime \prime}$ N, 015 43'35.1" E, 820 m (25); N38 - Lubelskie Province, E of Kamionka village, in forest at side of road between Kamionka and Firlej villages, 51 $28^{\prime} 52.8^{\prime \prime} \mathrm{N}, 022^{\circ} 28^{\prime} 19.0^{\prime \prime} \mathrm{E}, 157 \mathrm{~m}$ (25), trans; N61 - Mazowieckie Province, Płudy district of Warsaw, municipal forest, $52^{\circ} 20^{\prime} 08.6^{\prime \prime} \mathrm{N}, 020^{\circ} 58^{\prime}$ 39.8" E, 91 m (24), trans; N64 - Mazowieckie Province, fallow field near town of Radziejowice, on S side of main road between Warsaw and Mszczonów, 51 $59^{\prime} \mathrm{N}, 020^{\circ} 32^{\prime} \mathrm{E}$ (coordinates taken from map), $110 \mathrm{~m}$ (24); N67 - Pomorskie Province, Słajszewo village near Łeba city, 5445'51.0" N, 017²4'31.8' E, 24 m (25), trans; N68 - Warmińsko-Mazurskie Province, Lasy Taborskie forest near Ostróda city, on forest edge, $53^{\circ} 44^{\prime}$ 24.9" N, 01956'20.9" E, 55 m (13); N69 - Mazowieckie Province, near Glinojeck city, 5246'37.2" N, 020 $10^{\circ}$ 19.4" E, 98 m (24), trans; N70 - Świętokrzyskie Province, Wola Łagowska village near town of Łagów, fallow field 5045'53.5" N, 021 04'06.4" E, 320 m (25), trans; N71 - Świętokrzyskie Province, Paprocice village, $50^{\circ} 49^{\prime} 52.9^{\prime \prime} \mathrm{N}, 021^{\circ} 04^{\prime} 23.9^{\prime \prime} \mathrm{E}, 368$ m (25); N79 - Zachodnio-Pomorskie Province, Czapla village near Wałcz city, forest edge, 5315'41.0" N, 016³4'57.6" E, 120 m (24), trans; N80 - Warmińsko-Mazurskie Province, Olecko city, fallow field, 5401'12.9" N, 022 31'23.9" E, 174 m (25), trans; N81 - Podlaskie Province, Puszcza

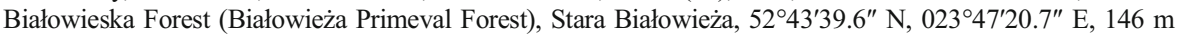
(23), trans; P39 - Pieniny Mts., E slope of Polenica Mt., 49²5'10.8' N, 020²0'32.7" E, 625 m (24); T19 Tatra Mts., Dolina Lejowa valley, forest on E slope of Cisowa Turnia Mt., 49 $16^{\prime} 33.9^{\prime \prime}$ N, 019 50'53.5" E, 942 m (23), trans; T26 - Tatra Mts., Dolina Kościeliska valley, forest by Zahradziska glade, on W slope of Kończysta Turnia peak, 49¹5'48.5" N, 01952'15.1" E, 947 m (14); T27 - Tatra Mts., Dolina Kościeliska 
valley, forest $\mathrm{N}$ of hiking trail to Polana na Stołach glade, 49 $15^{\prime} 17.7^{\prime \prime} \mathrm{N}, 019^{\circ} 51^{\prime} 51.3^{\prime \prime} \mathrm{E}, 1,010 \mathrm{~m}$ (25); T32 Tatra Mts., S slope of Przednia Kopa Sołtysia peak near Dolina Pańszczyca valley, 49¹6 $28.9^{\prime \prime}$ N, $020^{\circ} 03^{\prime} 35.8^{\prime \prime}$ E, 1,318 m (25); T33 - Tatra Mts., Kościeliskie Kopki hills between Dolina Kościeliska valley and Dolina Lejowa valley, pass between Pośrednia Kopka hill and Zadnia Kopka hill, near Świńska Turnia peak, 49 $15^{\prime}$ 43.5" N, 01951'21.7" E, 1,251 m (25); T40 - Tatra Mts., Dolina Bystrej valley, NW slope of Nosal peak, $49^{\circ} 16^{\prime}$ 43.9" N, 01958'59.9" E, 1,031 m (25); T43 - Tatra Mts., Staników Żleb gully between Dolina Kościeliska valley and Dolina Mała Łąka valley, 49¹6'22.5" N, 01952'53.6" E, 996 m (13); T53 - Tatra Mts., Dolina Bystrej valley, NW slope of Nosal peak, 49 $16^{\prime} 43.6^{\prime \prime} \mathrm{N}, 019^{\circ} 58^{\prime} 55.0^{\prime \prime} \mathrm{E}, 965 \mathrm{~m}$ (25), trans; T55 - Tatra Mts., Dolina Długa valley in Dolina Chochołowska valley, $49^{\circ} 15^{\prime} 35.5^{\prime \prime} \mathrm{N}, 019^{\circ} 48^{\prime} 14.6^{\prime \prime} \mathrm{E}, 1,071 \mathrm{~m}$ (24);

\section{Solidago minuta L.}

BG85 - Babia Góra Mt., N slope of Diablak summit, 49³4'27.5” N, 019³2'03.3" E, 1,690 m (21); K86 -

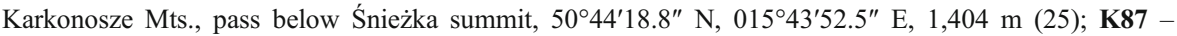
Karkonosze Mts., beneath pass below Śnieżka, 5044'27.6" N, 01543'52.8" E, 1257 m (15); K88 -

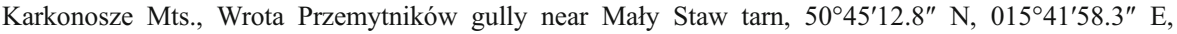
1,164 m (20); T01 - Tatra Mts., pass below Grześ Mt., 49¹4'18.5" N, 01946'24.0" E, 1,500 m (25); T02 - Tatra Mts., Dolina Goryczkowa valley, Niżnia Goryczkowa Polana glade, $49^{\circ} 14^{\prime} 46.2^{\prime \prime}$ N, $019^{\circ} 58^{\prime}$ 03.9" E, 1,318 m (13); T03 - Tatra Mts., Dolina Kondratowa valley, Polana Kondratowa glade, $49^{\circ} 14^{\prime}$ 55.3" N, 019 57'12.3" E, 1,357 m (25), trans; T04 - Tatra Mts., Długi Upłaz ridge between Grześ Mt. and Rakoń Mt., 49¹3'47.5" N, 01946'07.9" E, 1,622 m (16); T06 - Tatra Mts., Dolina Gąsienicowa valley, E slope of Uhrocie Kasprowe ridge, 4914'08.2" N, 01959'40.1" E, 1,650 m (25); T07 - Tatra Mts., E slope of Magura Mt., Królowa Rówień 49 $15^{\prime} 00.3^{\prime \prime}$ N, 02000'25.2" E, 1,563 m (25); T08 - Tatra Mts., Dolina Kościeliska valley, Polana na Stołach glade, 49¹4'55.2" N, 01951'12.6" E, 1,415 m (24); T09 - Tatra Mts., Dolina Pańszczyca valley, Polana Waksmundzka glade, 49¹5'31.7" N, 02003'36.6" E, 1,375 m (24); T10 - Tatra Mts., Dolina Suchej Wody valley, forest on W side of road to Dolina Gasienicowa valley, 49 16'22.9" N, 02002'05.8" E, 1,159 m (20); T11 - Tatra Mts., Dolina Małej Łąki valley, forest near Wyżnie Kolebiska 49 $15^{\prime} 13.2^{\prime \prime}$ N, 01954'52.5" E, 1,232 m (24); T12 - Tatra Mts., Dolina Małej Ląki valley, foot of Mnich Małołącki Mt., 49¹4'46.8" N, 01955'31.7" E, 1,460 m (25); T13 - Tatra Mts., Wyżnia Kondracka Przełęcz pass, 49 $14^{\prime} 55.8^{\prime \prime}$ N, 01956'05.2" E, 1,760 m (25); T14 - Tatra Mts., Dolina Pańszczyca valley, W slope of Koszysta ridge, 49¹4'55.8” N, 02002'25.1" E, 1,721 m (25); T15 - Tatra Mts., Wąwóz Kraków ravine in Dolina Kościeliska valley, Żleb Trzynastu Progów gully, 49¹3'58.8" N, 01953'12.8" E, 1,380 m (12); T17 - Tatra Mts., Dolina Kościeliska valley, forest W of Polana Smytnia glade, near hiking trail to Hala Ornak mountain hostel, 49¹3'58.3" N, 01951'31.8" E, 1,073 m (25); T18 Tatra Mts., Dolina Tomanowa valley, upper part of Kamienisty Żleb gully below Przełęcz Tomanowa pass,

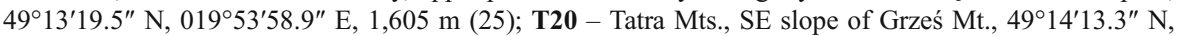
019 46'03.6" E, 1,630 m (24), trans; T21 - Tatra Mts., below summit of Wołowiec Mt. from on E side, 49 12'25.9" N, 01945'52.0" E, 2,040 m (25), trans; T22 - Tatra Mts., E slope of Jarząbczy Wierch Mt., 49¹2'17.6" N, 01948'19.4" E, 2,016 m (25), trans; T24 - Tatra Mts., Dolina Rybiego Potoku valley, SE slope of Miedziane ridge, Mnichowa Płaśń 49¹1'54.3" N, 02003'30.4" E, 1,670 m (25); T25 - Tatra Mts., Przełecz Szpiglasowa pass beneath summit of Szpiglasowy Wierch Mt., 49 $11^{\prime} 50.7^{\prime \prime}$ N, $020^{\circ} 02^{\prime} 27.5^{\prime \prime}$ E, 2,120 m (18), trans; T28 - Tatra Mts., Dolina Gąsienicowa valley, rock step of Zmarzły Staw tarn, 49 $13^{\prime} 32.3^{\prime \prime}$ N, 020 01' 21.5" E, 1,775 m (20), trans; T29 - Tatra Mts., Dolina Rybiego Potoku valley, scree above SE bank of Czarny Staw pod Rysami tarn, 49¹1'09.6" N, 02004'49.6" E, 1,652 m (24); T30 - Tatra Mts., Dolina Rybiego Potoku valley, scree above SE bank of Czarny Staw pod Rysami tarn, 49¹1'13.9" N, 02004'45.0" E, 1,590 m (25); T34 - Tatra Mts., Dolina Pięciu Stawów Polskich valley, N slope of Niżni Liptowski Kostur crag, $49^{\circ} 12^{\prime}$ 08.3" N, 020 01'58.0" E, 1,820 m (25), trans; T35 - Tatra Mts., Dolina Rybiego Potoku valley, N slope of Bula pod Rysami peak, $49^{\circ} 11^{\prime} 02.4^{\prime \prime} \mathrm{N}, 020^{\circ} 04^{\prime} 44.0^{\prime \prime}$ E, 1,724 m (25), trans; T36 - Tatra Mts., S crag of Mały Kozi Wierch peak, 49 $13^{\prime} 01.7^{\prime \prime}$ N, 020 01'14.7" E, 2,115 m (16), trans; T41 - Tatra Mts., Suchy Wierch Kondracki peak, 49 $14^{\prime} 02.7^{\prime \prime} \mathrm{N}, 019^{\circ} 56^{\prime} 37.6^{\prime \prime} \mathrm{E}, 1,850 \mathrm{~m}$ (21); T42 - Tatra Mts., Goryczkowa Czuba peak, 49 $13^{\prime} 55.2^{\prime \prime}$

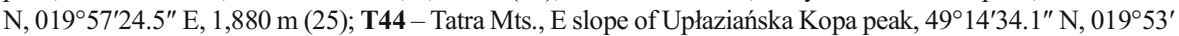
24.6" E, 1697 m (21), trans; T45 - Tatra Mts., Ciemniak summit, 49¹3'52.9" N, 01954'15.1" E, 2090 m (25), trans; T46 - Tatra Mts., Dolina Waksmundzka valley, Przysłop Waksmundzki beneath Gęsia Szyja hill, 49 $15^{\prime}$ 28.1" N, 02004'18.6" E, 1,446 m (25); T47 - Tatra Mts., Dolina Miętusia valley, W slope of Niedźwiedź hill, 49¹4'54.2" N, 01954'18.5" E, 1,411 m (25); T48 - Tatra Mts., Dolina Miętusia valley, S-exposed scree at foot of Litworowy Grzbiet ridge, 49¹4'36.8" N, 019 54'26.4" E, 1,531 m (24); T49 - Tatra Mts., Dolina Miętusia valley, Kobylarzowy Żleb gully, 49¹4'40.1" N, 01954'47.5" E, 1,802 m (25); T50 - Tatra Mts., Litworowa Przełęcz pass, 49¹3'59.5" N, 01954'49.9" E, 2,044 m (24), trans; T51 - Tatra 
Mts., NW slope of Twardy Grzbiet ridge beneath Ciemniak peak, 49¹4'09.2" N, 01953'47.4" E, 1,872 m (12);

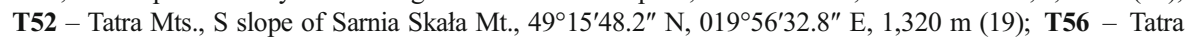
Mts., Dolina Tomanowa valley, lower part of Kamienisty Żleb gully below Tomanowa Przełęcz pass, $49^{\circ} 13^{\prime} 17.9^{\prime \prime} \mathrm{N}, 019^{\circ} 53^{\prime} 45.5^{\prime \prime}$ E, 1,481 m (25); T57 - Tatra Mts., Dolina Tomanowa valley, bottom of valley near Tomanowy Potok stream, 49 $13.5^{\prime} \mathrm{N}, 019^{\circ} 51.8^{\prime}$ (coordinates taken from map), 1,165 m (23); T58 - Tatra Mts., Dolina Rybiego Potoku valley, SE slope of Miedziane ridge, 49¹1'57.5" N, 02003'22.1" E, 1,775 m (23); T59 - Tatra Mts., Dolina Rybiego Potoku valley, Szeroki Żleb gully above Morskie Oko Lake, $49^{\circ} 11^{\prime}$ 55.7" N, 02003'51.4" E, 1,520 m (25); T60 - Tatra Mts., Dolina Rybiego Potoku valley, Marchwiczny Żleb gully above Morskie Oko Lake, 49 $12^{\prime} 05.1^{\prime \prime} \mathrm{N}, 020^{\circ} 04^{\prime} 04.4^{\prime \prime} \mathrm{E}, 1,435 \mathrm{~m}$ (25); T62 - Tatra Mts., Wrótka pass beneath Kopa Kalacka peak, 49¹5'17.9" N, 01957'14.3" E, 1,582 m (25); T66 - Tatra Mts., Dolina Rybiego Potoku valley, Bańdzioch cirque at foot of Mięguszowiecki Szczyt peak, 48 11'13.6" N, 020 03' 57.8" E, 1,901 m (19), trans; T78 - Tatra Mts., Dolina Rybiego Potoku valley, SE slope of Miedziane ridge, $49^{\circ} 11^{\prime} 52.1^{\prime \prime} \mathrm{N}, 020^{\circ} 03^{\prime} 04.5^{\prime \prime} \mathrm{E}, 1,860 \mathrm{~m}$ (11), trans; T84 - Tatra Mts., Dolina Bystrej valley, SE slope of Krokiew hill, $49^{\circ} 16^{\prime} 06.4^{\prime \prime} \mathrm{N}, 019^{\circ} 58^{\prime} 19.0^{\prime \prime} \mathrm{E}, 1,220$ m (15). 